\title{
Investigating the Effective Factors on Implementation of World Health Organization Package of Essential Non communicable Disease Interventions for Primary Health Care in Low Resource Settings: A Scoping review
}

Mina Aminpour ( $\nabla$ aminpour.m@iums.ac.ir)

Iran University of Medical Sciences https://orcid.org/0000-0001-6584-769X

Aidin Aryankhesal

Iran University of Medical Sciences

Nasrin Seyfori

Iran University of Medical Sciences

\section{Research article}

Keywords: WHO PEN, Essential Interventions for Non-Communicable Diseases, Primary Health Care, Implementation, scoping Review

Posted Date: June 8th, 2020

DOI: https://doi.org/10.21203/rs.3.rs-31010/v1

License: (c) (i) This work is licensed under a Creative Commons Attribution 4.0 International License. Read Full License 


\section{Abstract \\ Background/objective:}

Due to the widespread prevalence of non-communicable diseases, the World Health Organization has designed a package of essential interventions for non-communicable diseases for primary health care in low-resource settings. This study aimed to investigate the factors affecting the implementation of the WHO PEN for primary health care in low-resource settings.

\section{Materials and Methods}

This research was conducted through a five-step process of scoping review. We first searched for the keywords Noncommunicable Diseases, NCD, WHO PEN, PEN and other synonyms for these words to find the suitable analytical studies in databases including PubMed / MEDLINE, Scopus Cochrane Library, Web of Science, Google Scholar. The articles were then selected based on the PRISMA 2009 Flow Diagram. Finally, to analyze the content from the results section of the selected articles, we used the framework analysis method to extract the study implementation outcome and the factors affecting it.

\section{Results}

A total of 26 articles were included. Most articles are from 2016 to 2018. Most of the articles were cross-sectional and most studies evaluated the outcomes of Appropriateness and Feasibility. Identified effective factors include target population coverage, staff training, patient motivation, patient follow-up, and observance of PEN protocols.

\section{Conclusion}

Using this study, policymakers and managers of the health system will be able to implement this package (WHO PEN) more successfully.

\section{Background}

One of the challenges facing the health system in the world is the widespread prevalence of non-communicable diseases. The prevalence of non-communicable diseases is a global crisis. As predicted by $2020,60 \%$ of diseases and $73 \%$ of all deaths are expected to be related to non-communicable diseases(1). These diseases can be controlled by identifying risk factors and primary prevention. In 2013, the World Health Organization (WHO) designed a set of priority and effective interventions at the primary health care level in the form of a package of essential interventions for non-communicable diseases for primary health care to address the current challenge(2).

This package is an innovation and action-based response to existing challenges that is a set of priority and cost-effective interventions that can provide quality care even in the face of low resources. The package's main protocols include prevention of heart attacks, strokes and kidney disease through integrated diabetes and blood pressure care, health education and counselling on healthy behavioural diseases, asthma management, chronic obstructive pulmonary disease, and the evaluation and referral of women with suspected the lungs and uterus cancer(2). The purpose of such a package is to provide a fair framework for initiating the development of primary care because countries are working to achieve public access to health care. Therefore, WHO PEN should be an integral part of health care programs for the benefit of the poor, targeting vulnerable and disadvantaged groups. It should not be used as a means for care rationing in places where health care investment is insufficient despite existing resources due to poor management and leadership. As noted, the package should be considered as the minimum standard and only as a starting point for addressing NCDs in primary health care in low-resource settings(3). WHO PEN implementation increases national capacity to integrate and improve primary health care interventions for heart 
disease, stroke, cardiovascular risk, diabetes, cancer, asthma, and chronic obstructive pulmonary disease in low-resource settings(4).

The feasibility of implementing the high blood pressure and diabetes management protocol in the community-based prevention and control project was tested in China from April 2013 to August 2014. More than 2,000 primary care physicians from 200 public health centres in eight regions attended training sessions based on the WHO PEN protocol. Initial analysis of data from a screening of 300,000 People showed that awareness, treatment, and control of hypertension during project implementation were continuously improved and the risk of cardiovascular disease was reduced. At the same time, doctors have increased their skills in implementing the WHO PEN protocol in practice. The project showed that the WHO PEN would be particularly suitable for primary health care physicians in China(4).

A study conducted in Nepal following the implementation of the Non-Communicable Diseases Intervention (PEN) package for primary health care in low-resource settings revealed that the implementation of this PEN package provides opportunities to strengthen the workforce, diagnosis, medication and equipment, and health information system and research and monitoring and reducing inequality in diabetes care in Nepal, and the current state of health care facilities for the implementation of PEN has been assessed as satisfactory(5). In another study in Ghana, healthcare facilities lacked the capacity needed to properly implement WHO-PEN intervention. The results also highlight the lack of access to essential medicines needed to adequately manage NCDs at different levels of care(6). Another study, by assessing the facilities of eight LMIC countries, identified major shortages in financing, access to essential technologies and medicines, medical information systems, and the health care workforce(7). Another study was conducted to identify gaps and challenges in integrating diabetes care according to the WHO PEN protocol in Myanmar. The results show that the implementation of this protocol requires policy development for essential medicines and equipment, capacity building of health care workforce and referral system and appropriate health information system(8).

We define the outcomes of implementation in the present study as the effect of conscious and purposeful actions to implement new treatments, procedures and services. Implementation outcomes have three important functions. First, they act as indicators of implementation success. Second, they are approximate indicators of implementation processes, and third, they are key intermediate results about the service system or clinical outcomes in the effectiveness of treatment and the quality of care research. Since without successful implementation, intervention or treatment will not be effective. , the outcomes of its implementation will be used as a prerequisite for achieving the desired changes in clinical or service outcomes(9).

Since limited and scattered research has been conducted both in terms of outcomes and in terms of the type of implementation of the study, as well as the factors influencing the implementation of this package, and given the fact that the results of the science of implementation can improve routine health care in countries and communities with low resources, and the need for such results is certainly higher than in rich countries. In the present study, to achieve the predetermined goals of this WHO PEN program and to evaluate the implementation of its protocols, we intend to conduct a scoping review of the factors affecting the outcomes of implementation (Acceptability of the intervention, Adoption, Appropriateness, Cost, Feasibility, Fidelity, Penetration, Sustainability) of the Non-Communicable Diseases Intervention Package (WHO PEN) based on the conceptual framework expressed by Proctor et al(9) and identify and investigate the impact of interventions in the prevention of non-communicable diseases in setting with low resources.

One of the potential advantages of the scoping review is that it can provide an accurate and clear map of the areas of research(10). This study, in turn, makes it possible to identify gaps in the evidence base as well as to summarize and disseminate research findings. By providing results in an accessible and concise format, policymakers, stakeholders, and users to make effective use of the findings are in a better position.

\section{Methods}

In this study, using the five-step process of Arksey and O'Malley framework for scoping review, we investigated and identified the factors influencing the implementation of non-communicable disease intervention package for primary health care in 
settings with low resources(11). These steps include: identifying the research question, identifying the relevant studies, selecting the study, charting the data, and finally collecting, summarizing, and reporting the results. According to the framework of the scoping review used, our approach is similar to a narrative review that takes a broader view and Finally, the results are documented and is more comprehensible to readers.

In the first step, the research question, which Investigated the factors affecting the implementation of the package of noncommunicable diseases interventions for primary health care in environments with limited resources, was identified. In the second step, which is to identify the relevant studies, we first searched for keywords Noncommunicable Diseases, NCD, WHO PEN, PEN and other synonyms for these words to find suitable studies for analysis in databases including PubMed / MEDLINE, Scopus, Cochrane Library, Web of Science, Google Scholar.

In the third step, according to the inclusion criteria, including the structure of articles that have been evaluated based on the implementation of the Non-Communicable Diseases Intervention Package (WHO PEN) for primary health care, and the results achieved in each of the intended study implementation outcomes(Acceptability of the intervention, Adoption, Appropriateness, Cost, Feasibility, Fidelity, Penetration, Sustainability) between 2010, the time of the publication of the package (WHO PEN), until 2019, it was investigated and articles that did not meet the following criteria were excluded from the study: articles that were not in English, Articles that investigated other aspects of the package other than its implementation, articles that were not researched, articles that were not on a human subject. The researchers separately evaluated all related articles to classify studies according to inclusion criteria. Any discrepancies are discussed and a consensus was reached.

In the fourth step, the data of the selected articles were entered in the Excel database program. The content of data chart forms includes the following: author, year of publication, place of study, methodology, study objectives, important results that were identified and tabulated from selected articles. The data diagram was extracted to typology the articles using the Excel database software program. In the last step, according to the fifth step, Arksey and O'Malley framework for scoping review, for content analysis from the results section of selected articles, We used the framework analysis method to derive the outcome of implementation of the intended study and the factors affecting it.

In this study, we used a conceptual framework proposed by Proctor et al to synthesize the results and to understand the implications of implementation outcomes(9). In this model, a variety of outcomes in implementation research including Acceptability of the intervention, Adoption, Appropriateness, Cost, Feasibility, Fidelity, Penetration, Sustainability are introduced. The Proctor Framework was identified as the most appropriate conceptual framework for guiding the overall design of our study, as it was specifically developed to assess implementation activities in the field of healthcare(12). As shown in Figure 1.

\section{Results}

A total of 408 articles were extracted. Search results were saved from each database in EndNote X9 and duplicate articles were removed, Finally, 354 articles remained. In the next step, by checking the titles and abstracts of the articles, they were screened based on the inclusion and exclusion criteria of the articles, as a result of which 318 articles were removed and 36 articles remained. In the last step, by reviewing the full text of the articles, 26 articles were found for the final review. Figure 2 shows the steps for selecting articles based on the PRISMA 2009 Flow Diagram. After reading all the selected articles, the authors summarized the data of the selected articles based on Table 1. (As Table1 larger than one Letter page in length is placed at the end of the document text file.)

This program (WHO PEN) is designed for countries with a shortage of resources (LMIC). WHO member states are classified as low- and middle-income countries (LMICs) (6 WHO regions are used), and high-income countries divide each of these regions into a seventh group. Out of a total of 26 studies, one study is from 8 LMIC countries. Most of the studies are on Bhutan. A total of 18 single-country studies have been conducted. Most of the articles were published in 2016, 2017 and 2018. The most common type of article is among the 26 selected articles, cross-sectional survey articles with 9 articles and Commentary, perspective articles.

Page 4/31 
Based on the conceptual model of the present study, articles related to each of the factors affecting the implementation of the NonCommunicable Diseases Intervention Package (WHO PEN) for primary health care were identified and coded and categorized based on the outcomes of the implementation of the study (Acceptability of the intervention, Adaptation, Appropriateness, Cost, Feasibility, Fidelity, Penetration, Sustainability). Some studies, such as feasibility studies, have explicitly described and evaluated that aspect of the implementation factors that are feasibility. However, in some articles, by reading the full text and the questions and results obtained, based on the analysis of the framework, the desired outcome that the study sought to evaluate was extracted. Of the eight study outcomes, 6 outcomes were evaluated based on the articles, including Adaptation, Appropriateness, Cost, Feasibility, Fidelity, and Penetration, most of which evaluated the Appropriateness outcome. Finally, the factors affecting the implementation outcomes that were evaluated in each article were extracted and included in the subset of 4 categories include individual factors affecting the implementation of the program, factors related to the program, factors related to the organizational field, factors related to the external field. The classification of effective factors is based on the 4 categories mentioned in Table 2 . The effective factors based on each of the outcomes of implementing the WHO PEN program are described below.

\section{Adoption}

Adoption refers to the proportion and representation of areas (such as worksites, health departments, or communities) that adopt a particular policy or program(34). Adoption is defined as the goal, initial decision, or action to attempt or apply evidence-based innovation or action(35). Adaptation means "the process of creating a program to create as much as possible for a particular population or organization, based on its capacity. Change in a program must be done without compromising or destroying the core components of the program"(36), is defined. In this study, we outlined adaptation is one of the outcomes: In a study conducted to strengthen the relationship between health care and community services in Samoa, the word adaptation was used to assess the level of acceptance and coverage of the population. This program was covered(14) based on the definition of Adaptation, it was decided to include this article as an article on the Adaptation aspect in the Adoption group. Factors influencing the outcomes of adaptation include a focused community-based approach, monitoring the progress of intervention over time using data management, providing screening results to the community, and raising awareness of the nature of the early stages of NCDs.

\section{Appropriateness}

Appropriateness is the perceived fit, relevance, or adaptability of innovation or evidence-based action to a set of activities, provider, or consumer, or understanding of innovation to address a particular issue or problem. "Appropriateness" is conceptually similar to "acceptance," and literature, when discussing these structures, shows overlapping and sometimes contradictory terms (9).

In this study, a total of 10 articles are related to this type of outcome. Examining these articles, the factors influencing the outcome of "Appropriateness " include individual factors such as more accurate physical examination by a physician, more time with a physician, a better understanding of medication prescription, patient adherence to monthly visits to the intervention group due to advanced patient education, messaging SMS and components of telephone reminders, patient motivation, health education messages. 
Organizational factors were such as availability of necessary equipment and medicines, referral systems, use of monitoring tools, training of rural health workers, lack of time, lack of staff, shorter waiting time, use of a time-setting system, no increase the follow-up period between visits, the importance of the division of labour, simple workflow, health information and research system, the existence of supportive technologies, Informed and supportive managers, recording basic demographic and clinical information, capacity building for health system research and training, better organization of testing Laboratory.

Program factors were identified such as patient follow-up, clinical trials, PEN Operations Manual, population coverage, accurate patient data recording, the changes measurement in population and not in patients, encouragement and follow-up of patients via mobile phones and Home visits, physician use of risk prediction charts and scores, training for newcomers, lifestyle counseling, intervention quality maintenance, target population coverage, opportunistic screening, evidence-based interventions, Complications monitoring, clear referral criteria and Participatory health care services, regular blood pressure measurements, Waist circumference and weight, Multilateral and frequent training, maintaining the quality of the intervention, regular approaches to identifying the target population and achieving coverage, engaging patients, the importance and priority of staff training to assess CVD risk, supporting the use of CVD risk charts as a communication tool, Expanding risk scoring on a larger scale, individual counseling, and the entire riskbased CVD algorithm.

External and environmental factors were identified such as budget allocation in annual programs, communication with local physicians, targeting public health myths in the community, barriers to access to patients such as distance and complex travel.

\section{Cost}

The cost of implementation is defined as the cost of an executive effort. Implementation costs vary according to the three components. First, because the Treatments are very different in terms of their complexity, the cost of providing them will be different. Second, the cost of implementation will vary depending on the complexity of the specific used implementation strategy. Finally, because the treatments are performed with different areas and complexities (from the individual physician's workplace to a third-level care centre), the overall cost of providing services in each area will vary. Therefore, the actual cost of implementing a treatment depends on the cost of the particular intervention, the strategy used, and the location of delivering services(9). In the present study, 3 articles have done an economic evaluation of the "WHO PEN" program. The results of two studies confirmed the cost-effectiveness of the WHO PEN program. In another study that was compared the program to another program in terms of cost-effectiveness, WHO PEN was less cost-effective. Factors influencing the outcome of the "cost" identified in these studies include the justification of widespread and common treatment, the Utilization of a specific population deprived of treatment, the prioritization of risk factors, the explicit and clear focus of guidelines on justice, significantly high population coverage under treatment, screening public health as a priority for the spread of screening, the prevalence of the disease, the falling rate of the relative risk of death from kidney disease, and The relative risk of death from controlled and uncontrolled blood pressure.

\section{Feasibility}

Page 6/31 
Feasibility means how can be successful a new treatment or innovation in an agency or a specific location and using (37). In the present study, most of the articles based on WHO PEN Tool measured the capacity and readiness of health care centres to implement the program in five areas including basic equipment, essential services, diagnostic capacity, counselling services and essential medications(2). Identified effective factors include the effectiveness of WHO PEN tools for ranking center performance, the effectiveness of WHO PEN tools to achieve NCD goals and prioritization, staff training, equipping centers, the availability of essential drugs, and the provision of quality services, Adequate training and skills in the use of some intervention technologies for early diagnosis and diagnosis, the existence of clear guidelines and policies to include promotion and prevention actions, the availability of basic equipment, basic diagnostic tests, medication and access to referral centers and medical records, Medical Information Management System, continuous and periodic monitoring of the capacity of centers during time, frequent monitoring and measurement of indicators of delivering medical services, the importance of scale up low cost and effective interventions, strengthening the capacity of health workers, access to basic technologies and essential drugs, training and empowerment of nonphysician health workers, removing barriers to continued care By strengthening the medical information system, low quality of service due to lack of sufficient financing, the ability of family physicians to implement protocols and risk assessment, increasing people's awareness, screening, patient follow-up, free medication from nearby healthcare centers, regular consumption of Medications.

\section{Fidelity}

Fidelity is defined as the extent to which an intervention is performed as intended in the original protocol or as intended by program developers(38). In this study, only one article was identified to evaluate this outcome. In this article, the observance of WHO PEN protocols by staff is measured by reviewing files in health centres. The only effective factor is the degree of matching of data entry in the file, as well as the actions and follow-ups performed by the staff according to the WHO PEN program protocols.

\section{Penetration}

"Penetration" is defined as the integration of an action into a service setting and its subsystems(9). In this study, 3 articles evaluated this outcome of implementation. The most important factors identified in these articles include the commitment of the highest administrative authority, strong leadership of the Ministry of Health, integration of policymaking and services delivery, a coordination mechanism, cooperation of women representatives as community health workers, integration of national policies on NCDs in national health policy and development of a strategic action plan with national goals by global and regional voluntary goals, strengthening the multi-sectoral coordination mechanism, emphasizing the production of qualified human resources for healthcare delivery focusing on the quantity, quality and categories required by the health workforce.

Table 2. the Effective Factors on Implementation of WHO PEN 


\begin{tabular}{|c|c|c|c|}
\hline Organizational factors & Program factors & individual factors & External and environmental factors \\
\hline $\begin{array}{l}\text { Resources (human and material): } \\
\text { Reuse and rehabilitate existing manpower } \\
\text { staff training } \\
\text { Adequate training and skills in the use of } \\
\text { some intervention technologies for early } \\
\text { diagnosis and diagnosis strengthening the } \\
\text { capacity of health workers } \\
\text { Informed and supportive managers } \\
\text { emphasizing the production of qualified } \\
\text { focusing on the quantity, quality and } \\
\text { categories required by the health workforce } \\
\text { the availability of basic equipment, basic } \\
\text { diagnostic tests, medication } \\
\text { capacity building for health system } \\
\text { research and training } \\
\text { removing barriers to continued care By } \\
\text { sechnology: } \\
\text { information } \\
\text { Existence of supportive technologies }\end{array}$ & 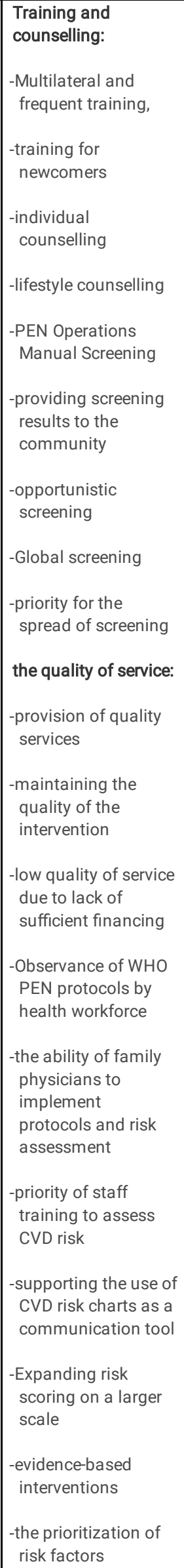 & $\begin{array}{l}\text {-the justification of widespread and } \\
\text { common treatment } \\
\text {-patient adherence to monthly visits to the } \\
\text { intervention group due to advanced } \\
\text { patient education, messaging. SMS and } \\
\text { components of telephone reminders } \\
\text {-a better understanding of medication } \\
\text { prescription } \\
\text {-more accurate physical examination by a } \\
\text { physician } \\
\text {-patient motivation } \\
\text {-increasing people's awareness } \\
\text {-health education messages } \\
\text {-free medication from nearby healthcare } \\
\text { centres } \\
\text {-regular consumption of Medications. } \\
\text {-engaging patients } \\
\text {-more time with a physician } \\
\text {-raising awareness of the nature of the }\end{array}$ & $\begin{array}{l}\text {-the commitment of the highest } \\
\text { administrative authority } \\
\text { - strong leadership of the Ministry of Health } \\
\text {-integration of national policies on NCDs in } \\
\text { national health policy and development of a } \\
\text { strategic action plan with national goals by } \\
\text { global and regional voluntary goals } \\
\text {-strengthening the multi-sectoral coordination } \\
\text { mechanism } \\
\text {-the prevalence of the disease } \\
\text {-communication with local physicians } \\
\text {-Consequences of EML National Selection on } \\
\text { Population Access to Drugs } \\
\text {-Review and update governments on their } \\
\text { ELMs } \\
\text {-the explicit and clear focus of guidelines on } \\
\text { justice }\end{array}$ \\
\hline
\end{tabular}




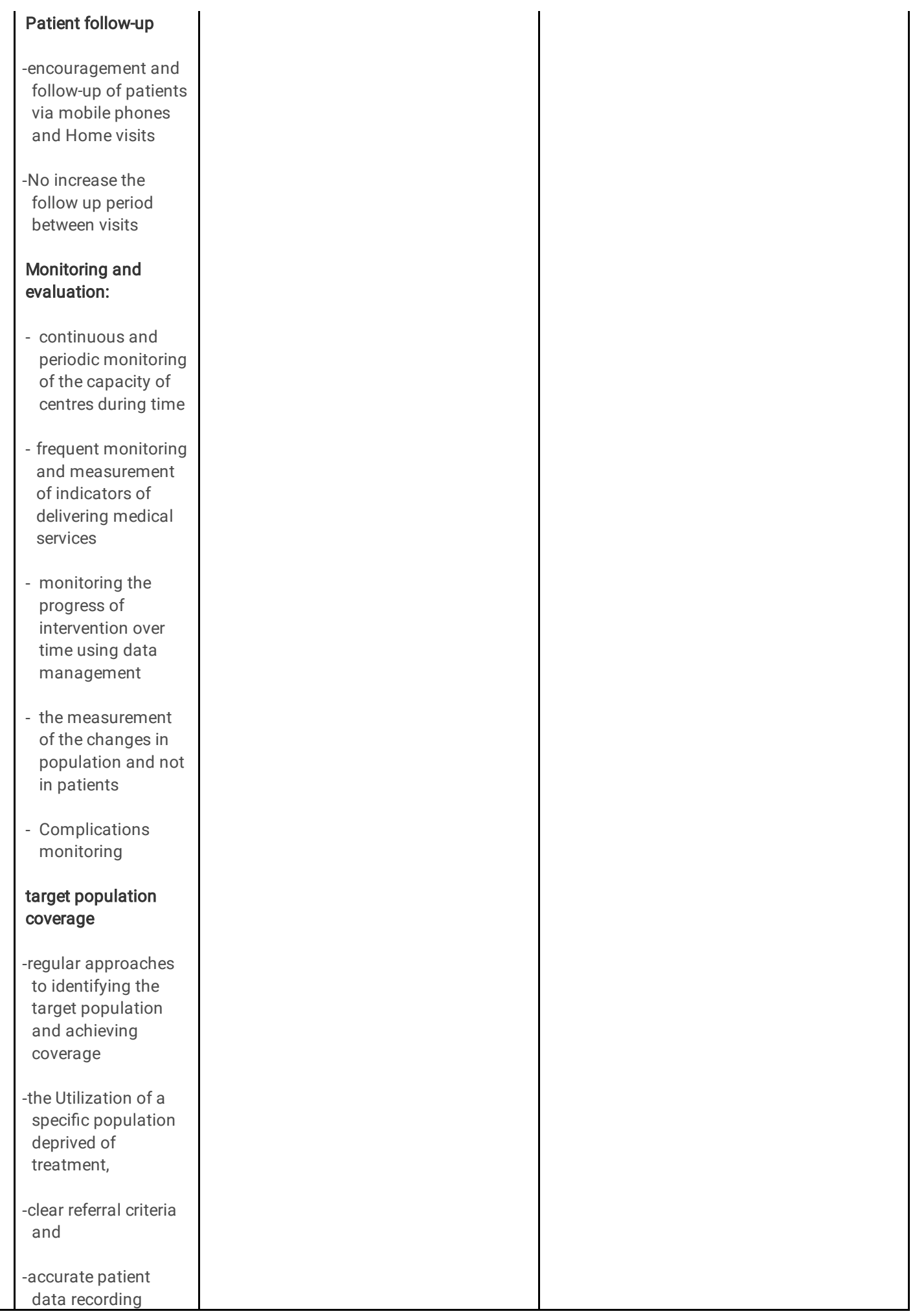

\section{Discussion}

This scoping review was conducted to investigate the effective factors the implementation of world health organization package of essential non-communicable disease interventions for primary health care in low resource settings. 26 articles came into our study, each evaluating the outcomes of implementation. The most common type of article includes crosssectional study articles. Out of a total of 26 studies, one study is from 8 LMIC countries. Most of the studies are on Bhutan. A total of 18 single-country studies have been conducted. Most articles were published in 2016 to 2018. 
World health organization package of essential non-communicable disease interventions for primary health care in low resource settings (WHO PEN) to activate early diagnosis and management at the primary care level in low-resource settings. WHO PEN is a set of prioritized cost-effective interventions that can provide an acceptable quality of service at a low cost. These interventions have the minimum standards for non-communicable diseases, strengthening national capacity to integrate and expand care for heart disease, stroke, risk of cardiovascular disease, diabetes, cancer, asthma and chronic obstructive pulmonary disease in primary health care in low-resource settings(3). Therefore, in the present study, we tried to get a comprehensive view of the studies that evaluated the implementation of this package. In this regard, we used the conceptual framework of implementation of Proctor et al. Of the eight study outcomes, 6 were evaluated based on articles, including Adaptation, Appropriateness, Cost, Feasibility, Fidelity, and Penetration, and most of the articles were evaluated for Appropriateness. None of the studies evaluated the outcome of Acceptability and Sustainability.

Acceptability should be assessed based on the stakeholder's knowledge or direct experience with the various dimensions of the treatment to be performed, such as its content, complexity, or comfort. Acceptability differs from the broader structure of service satisfaction; satisfaction is typically measured through consumer surveys. Acceptability is more specific, referring to a specific treatment or set of treatments, while satisfaction typically refers to the experience of public services, including features such as waiting time, planning, and environmental conditions. Acceptability may be measured from the perspective of different stakeholders, such as supervisors, payers, providers, and consumers(9). Therefore, according to the framework used in this study, there is a lack of study in the field of evaluating the acceptance or Acceptability of the program by the stakeholders of the program.

About Sustainability, Rabin et al(2008) emphasize the integration of a specific program in the culture of the organization through policies and practices and identify three steps that determine institutionalization: 1- Transition (a single event Such as transition from temporary to permanent budget), 2- cycle or routine (It means frequent reinforcement of the importance of evidence-based intervention by incorporating it into organizational or community practices and behaviours, such as annual budgets and evaluation criteria) and 3- niche saturation ( The degree of integration of evidence-based intervention in all subsystems of an organization(35); In fact, Steckler et al(1992) emphasize sustainability in terms of achieving long-term durability as the final stage of the dissemination process in which innovations are established in organizations(39). Unfortunately, no study has been done in this scope.

Factors affecting the outcomes of implementing the WHO PEN program include four categories of factors related to the organizational context, individual factors, factors related to the program and factors related to the context and environment. In general, some of the most important factors related to the organizational context are strengthening the capacity of health workers, Informed and supportive managers, the importance of division of labour, a coordination mechanism, the use of a timesetting system, and so on. The most important factors related to the program are opportunistic screening, follow-up of patients, observance of WHO PEN protocols by employees, accurate recording of patient data, regular approaches in identifying the target population and achieving coverage, etc. One of the most important individual factors in the implementation of WHO PEN program is the patient's adherence to monthly visits to the intervention group due to advanced patient education, SMS messaging and telephone reminder components, patient motivation, increasing people's awareness, regular medication use. Commitment of the highest administrative official, strong leadership of the Ministry of Health, strengthening the multi-sectoral coordination mechanism, etc are effective factors resulting from the external environment. Quantitative studies have identified effective individual factors (such as program participants, stakeholders, etc.) and external factors.

\section{Conclusions}

The results of this study show that there are few studies on the outcomes of the implementation of this program. Since evaluating the implementation of a program is considered one of the evidence of success in the implementation of that program, therefore, according to this study, research design is recommended in terms of the outcomes that were not studied. The study also identified and explained the factors influencing the implementation of the program (WHO PEN) that facilitate the successful implementation of this program, or the obstacles to its implementation to support its successful implementation 
in Primary healthcare requires that they be removed. Therefore, according to the effective factors identified in this study, policymakers and managers of the health system will be more successful in implementing this package (WHO PEN).

\section{Abbreviations}

WHO PEN; World Health Organization Package of Essential Non-communicable Disease Interventions; PRISMA: Preferred Reporting Items for Systematic Reviews and Meta-Analyses; WHO: World Health Organization

\section{Declarations}

- Ethics approval and consent to participate:

Not applicable.

\section{- Consent to publish:}

Not applicable.

\section{- Availability of data and materials:}

The datasets used and/or analysed during the current study are available from the corresponding author on reasonable request.

\section{- Competing interests:}

There are no competing interests to declare.

\section{- Funding:}

This study was part of a research project that is supported by the health management and economics research center affiliated to Iran University of Medical Sciences (Project No. 98-2-48-15640 and Ethical Code. IR.IUMS.REC.1398.722).

\section{- Authors' contributions:}

MiA, AiA and NaS designed the study. MiA and AiA collected the data and performed the data analysis. All authors edited and revised the paper for grammar. All authors read and approved the final paper for publication.

\section{- Acknowledgements:}

Not applicable.

\section{Author details:}


Health Management and Economics Research Center, Iran University of Medical Sciences

, Tehran, Iran. Mina Aminpour

School of Health Management and Information Sciences, Iran University of Medical Sciences, Tehran, Iran. Aidin Aryankhesal, Nasrin Seyfori

\section{References}

1. Hojjatzadeh e, Heydari A, Samavat T. The effect of health behvarz' education level on blood pressure control among hypertensive patients in the rural areas of Qazvin city, Iran \%J Journal of School of Public Health and Institute of Public Health Research. 2016;13(4):13-24.

2. Implementation tools, package of essential non-communicable (PEN) disease interventions for primary health care in lowresource settings [Internet]. Organization WH. 2013. Available from: https://www.who.int/ncds/management/pen_tools/en/.

3. Package of essential noncommunicable disease (PEN) interventions for primary health care in low-resource settings. [Internet]. Geneva: World Health Organization. 2010. Available from:

http://www.who.int/nmh/publications/essential_ncd_interventions_Ir_settings.pdf.

4. Zhang XH, Lisheng L, Campbell NR, Niebylski ML, Nilsson P, Lackland DT. Implementation of World Health Organization Package of Essential Noncommunicable Disease Interventions (WHO PEN) for Primary Health Care in Low-Resource Settings: A Policy Statement From the World Hypertension League. Journal of clinical hypertension (Greenwich, Conn). 2016;18(1):5-6.

5. Upreti SR, Lohani GR, Magtymova A, Dixit LP. Strengthening policy and governance to address the growing burden of diabetes in Nepal. WHO South-East Asia journal of public health. 2016;5(1):40-3.

6. Nyarko KM, Ameme DK, Ocansey D, Commeh E, Markwei MT, Ohene SA. Capacity assessment of selected health care facilities for the pilot implementation of Package for Essential Non-communicable Diseases (PEN) intervention in Ghana. The Pan African medical journal. 2016;25(Suppl 1):16.

7. Mendis S, Al Bashir I, Dissanayake L, Varghese C, Fadhil I, Marhe E, et al. Gaps in capacity in primary care in low-resource settings for implementation of essential noncommunicable disease interventions. International journal of hypertension. 2012;2012:584041.

8. Latt TS, Aye TT, Ko K, Zaw KK. Gaps and challenges to integrating diabetes care in Myanmar. WHO South-East Asia journal of public health. 2016;5(1):48-52.

9. Proctor E, Silmere H, Raghavan R, Hovmand P, Aarons G, Bunger A, et al. Outcomes for implementation research: conceptual distinctions, measurement challenges, and research agenda. Administration and policy in mental health. 2011;38(2):65-76.

10. Peters M, Godfrey C, Khalil H, Mclnerney P, Parker D, Soares C. Guidance for conducting systematic scoping reviews. International journal of evidence-based healthcare. 2015;13.

11. Arksey H, O'Malley L. Scoping studies: towards a methodological framework. International Journal of Social Research Methodology. 2005;8(1):19-32.

12. Sharplin G, Adelson P, Kennedy K, Williams N, Hewlett R, Wood J, et al. Establishing and Sustaining a Culture of EvidenceBased Practice: An Evaluation of Barriers and Facilitators to Implementing the Best Practice Spotlight Organization Program in the Australian Healthcare Context. Healthcare (Basel, Switzerland). 2019;7(4).

13. Baghirov R, Ah-Ching J, Bollars C. Achieving UHC in Samoa through Revitalizing PHC and Reinvigorating the Role of Village Women Groups. Health systems and reform. 2019;5(1):78-82.

Page $12 / 31$ 
14. Bollars C, Naseri T, Thomsen R, Varghese C, Sorensen K, Vries N, et al. Adapting the WHO package of essential noncommunicable disease interventions, Samoa. Bulletin of the World Health Organization.96:578-83.

15. Dorji T, Yangchen P, Dorji C, Nidup T, Zam K. An approach to diabetes prevention and management: The Bhutan experience. WHO South-East Asia journal of public health. 2016;5(1):44-7.

16. Mutale W, Bosomprah S, Shankalala P, Mweemba O, Chilengi R, Kapambwe S, et al. Assessing capacity and readiness to manage NCDs in primary care setting: Gaps and opportunities based on adapted WHO PEN tool in Zambia. PloS one. 2018;13(8):e0200994.

17. Ahir G. Assessment Of Facility-Level Preparedness At Primary And Secondary Health Care Levels For Prevention And Control Of Non-Communicable Diseases: Assessment Of Facility-Level Preparedness For Prevention And Control Of NonCommunicable Diseases. National Journal of Integrated Research in Medicine. 2019;9(6):36-9.

18. Aryal BK, Daud M, Thapa A, Mahotra A, Ale Magar S, Malla CK. Assesssment of Health Facilities for Implementation of Noncommunicable Disease Package. Journal of Nepal Health Research Council. 2018;16(2):149-55.

19. Bawazir AA, Al-Surimi K, Suwaidan SD, AlShehri AM, AlFarhan Al, Aboulfotouh MA. Capacity and readiness of primary health care centers for implementation of the basic strategy for prevention and control of non-communicable diseases in Saudi Arabia. A case study from the Ministry of National Guard-Health Affairs, Riyadh, Saudi Arabia. Saudi medical journal. 2019;40(6):614-8.

20. Rogers HE, Akiteng AR, Mutungi G, Ettinger AS, Schwartz JI. Capacity of Ugandan public sector health facilities to prevent and control non-communicable diseases: an assessment based upon WHO-PEN standards. BMC health services research. 2018;18(1):606.

21. Collins DRJ, Jobanputra K, Frost T, Muhammed S, Ward A, Shafei AA, et al. Cardiovascular disease risk and prevention amongst Syrian refugees: mixed methods study of Médecins Sans Frontières programme in Jordan. Confl Health. 2017;11:14-.

22. Dweakat R, Barghouthi N, Bouziyeh Y, Abu-Hijleh R, Ramlawi A, Shamasnah I, et al. Clinical audit to assess quality of service in a newly implemented NCD programme: a cross-sectional survey to review a pilot implementation of the WHO PEN approach in Salfit district, occupied Palestinian territory. The Lancet. 2017;390:S28.

23. Khan MA, Walley JD, Khan N, Hicks J, Ahmed M, Khan SE, et al. Effectiveness of an integrated diabetes care package at primary healthcare facilities: a cluster randomised trial in Pakistan. BJGP Open. 2018;2(4):bjgpopen18X101618-bjgpopen18X.

24. Kontsevaya A, Farrington J. Implementation of a package of essential noncommunicable (PEN) disease interventions in Kyrgyzstan: evaluation of effects and costs in Bishkek after one year World Health Organization; 2017 [Available from: http://www.euro.who.int/_data/assets/pdf_file/0011/337844/PEN-Evaluation-ENG-FINAL.pdf?ua=1.

25. Barghouthi N, Dweakat R, Bouziyeh Y, Abu-Hijleh R, Shamasnah I, Ramlawi A, et al. Implementation of WHO package of essential non-communicable disease interventions in the occupied Palestinian territory: assessment of patient perceptions to changes in quality of care with participatory ranking methods. The Lancet. 2017;390:S27.

26. Basu S, Wagner RG, Sewpaul R, Reddy P, Davies J. Implications of scaling up cardiovascular disease treatment in South Africa: a microsimulation and cost-effectiveness analysis. The Lancet Global health. 2019;7(2):e270-e80.

27. Collins D, Farrington J, Kontsevaya A, Altymysheva A. Improving the implementation of a package of essential noncommunicable (PEN) disease interventions in Kyrgyzstan: mixed methods service evaluation of pilot health centres: World Health Organization 2017 [Available from: http://www.euro.who.int/_data/assets/pdf_file/0011/355961/PENimplementation.pdf?ua=1. 
28. Dukpa W, Teerawattananon Y, Rattanavipapong W, Srinonprasert V, Tongsri W, Kingkaew P, et Is diabetes and hypertension screening worthwhile in resource-limited settings? An economic evaluation based on a pilot of a Package of Essential Noncommunicable disease interventions in Bhutan. Health policy and planning. 2015;30(8):1032-43.

29. Rattanavipapong W, Luz ACG, Kumluang S, Kusumawardani N, Teerawattananon Y, Indriani CD, et al. One Step Back, Two Steps Forward: An Economic Evaluation of the PEN Program in Indonesia. Health systems and reform. 2016;2(1):84-98.

30. Hyon CS, Nam KY, Sun HC, Garg R, Shrestha SM, Ok KU, et al. Package of essential noncommunicable disease (PEN) interventions in primary health-care settings in the Democratic People's Republic of Korea: A feasibility study. WHO South-East Asia journal of public health. 2017;6(2):69-73.

31. Wangchuk D, Virdi NK, Garg R, Mendis S, Nair N, Wangchuk D, et al. Package of essential noncommunicable disease (PEN) interventions in primary health-care settings of Bhutan: a performance assessment study. WHO South-East Asia journal of public health. 2014;3(2):154-60.

32. Jarvis JD, Woods H, Bali A, Oronsaye E, Persaud N. Selection of WHO-recommended essential medicines for noncommunicable diseases on National Essential Medicines Lists. PloS one. 2019;14(8):e0220781.

33. Martinez RE, Quintana R, Go JJ, Villones MS, Marquez MA. Use of the WHO Package of Essential Noncommunicable Disease Interventions after Typhoon Haiyan. Western Pacific surveillance and response journal : WPSAR. 2015;6 Suppl 1:18-20.

34. Emont SL, Choi WS, Novotny TE, Giovino GA. Clean indoor air legislation, taxation, and smoking behaviour in the United States: an ecological analysis. Tob Control. 1993;2(1):13-7.

35. Rabin BA, Brownson RC, Haire-Joshu D, Kreuter MW, Weaver NL. A glossary for dissemination and implementation research in health. Journal of public health management and practice : JPHMP. 2008;14(2):117-23.

36. Rolleri LA, Fuller TR, Firpo-Triplett R, Lesesne CA, Moore C, Leeks KD. Adaptation Guidance for Evidence-Based Teen Pregnancy and STI/HIV Prevention Curricula: From Development to Practice. American journal of sexuality education. 2014;9(2):135-54.

37. Karsh BT. Beyond usability: designing effective technology implementation systems to promote patient safety. Quality \& safety in health care. 2004;13(5):388-94.

38. Dusenbury L, Brannigan R, Falco M, Hansen WB. A review of research on fidelity of implementation: implications for drug abuse prevention in school settings. Health education research. 2003;18(2):237-56.

39. Steckler A, Goodman RM, McLeroy KR, Davis S, Koch G. Measuring the diffusion of innovative health promotion programs. American journal of health promotion : AJHP. 1992;6(3):214-24.

\section{Table 1}

Table 1.SUMMARY OF STUDIES INCLUDED IN THIS REVIEW 


\begin{tabular}{|c|c|c|c|c|c|c|}
\hline & $\begin{array}{l}\text { Author(s) } \\
\text { (publication } \\
\text { year) } \\
\text { Focus country }\end{array}$ & $\begin{array}{l}\text { Sample / Type and } \\
\text { method of article }\end{array}$ & Study Type & Study aims & $\begin{array}{l}\text { Implementation } \\
\text { outcome }\end{array}$ & $\begin{array}{l}\text { results related to the } \\
\text { research question }\end{array}$ \\
\hline 1 & $\begin{array}{l}\text { Baghirov et al. } \\
\text { (2019) } \\
\text { Samoa(13) }\end{array}$ & Commentary & Qualitative & $\begin{array}{l}\text { To describe the } \\
\text { important } \\
\text { historical and } \\
\text { cultural role of } \\
\text { women in } \\
\text { accelerating } \\
\text { progress towards } \\
\text { UHC }\end{array}$ & Penetration & $\begin{array}{l}\text { Preliminary results of } \\
\text { the program } \\
\text { implementation are } \\
\text { positive. PEN Fa'a } \\
\text { Samoa achieved a } \\
\text { high level of } \\
\text { population screening } \\
\text { coverage in the } \\
\text { demonstration villages, } \\
\text { in which the women's } \\
\text { committee } \\
\text { representatives played } \\
\text { a key role. } \\
\text { More than } 90 \% \text { of the } \\
\text { target population has } \\
\text { been screened for } \\
\text { NCDs. }\end{array}$ \\
\hline 2 & $\begin{array}{l}\text { Caroline Bollars } \\
\text { et al. (2018) } \\
\text { Samoa(14) }\end{array}$ & $\begin{array}{l}\mathrm{N}=2234 \text { adults/ } \\
\text { The conceptual } \\
\text { development of the } \\
\text { three-step package } \\
\text { took place from } \\
\text { September to } \\
\text { December } 2014 \text {, and } \\
\text { screening at the } \\
\text { pilot sites occurred } \\
\text { from February to } \\
\text { March } 2015 .\end{array}$ & Quantitative & $\begin{array}{l}\text { strengthening } \\
\text { links between } \\
\text { health services } \\
\text { and the } \\
\text { community; } \\
\text { and meeting the } \\
\text { global target of at } \\
\text { least } 50 \% \text { of } \\
\text { eligible people } \\
\text { receiving } \\
\text { treatment and } \\
\text { counselling } \\
\text { through early } \\
\text { detection and } \\
\text { management of } \\
\text { noncommunicable } \\
\text { diseases }\end{array}$ & Adaptation & $\begin{array}{l}\text { As a result of the Fa'a } \\
\text { Samoa intervention } \\
\text { package, those high- } \\
\text { risk members of the } \\
\text { population were made } \\
\text { aware of their risk } \\
\text { status and were } \\
\text { motivated to seek } \\
\text { treatment or manage } \\
\text { risk factors. Village } \\
\text { members learned } \\
\text { about the risk of } \\
\text { noncommunicable } \\
\text { diseases at organized } \\
\text { sessions, which } \\
\text { brought villagers } \\
\text { together and translated } \\
\text { findings into their } \\
\text { language and } \\
\text { understanding. By } \\
\text { being made aware that } \\
\text { such diseases have no } \\
\text { symptoms in their } \\
\text { early stages, the } \\
\text { cultural belief that } \\
\text { illness is only present } \\
\text { when a person feels ill } \\
\text { was overcome. }\end{array}$ \\
\hline 3 & $\begin{array}{l}\text { Dorji et al. (2016) } \\
\text { Bhutan(15) }\end{array}$ & Perspective & Qualitative & $\begin{array}{l}\text { Presentation and } \\
\text { review of Bhutan's } \\
\text { experience in WHO } \\
\text { PEN } \\
\text { implementation } \\
\text { and prevention } \\
\text { and management } \\
\text { of diabetes }\end{array}$ & Appropriateness & $\begin{array}{l}\text { 1. The proportion } \\
\text { of patients who } \\
\text { were followed } \\
\text { up was high, } \\
\text { owing to the } \\
\text { involvement of } \\
\text { non-physician } \\
\text { health workers, } \\
\text { who also } \\
\text { conducted } \\
\text { home visits. } \\
\text { 2. During the pilot } \\
\text { in } 2009 \text {, the } \\
\text { implementation } \\
\text { of PEN } \\
\text { interventions led }\end{array}$ \\
\hline
\end{tabular}

Page 15/31 


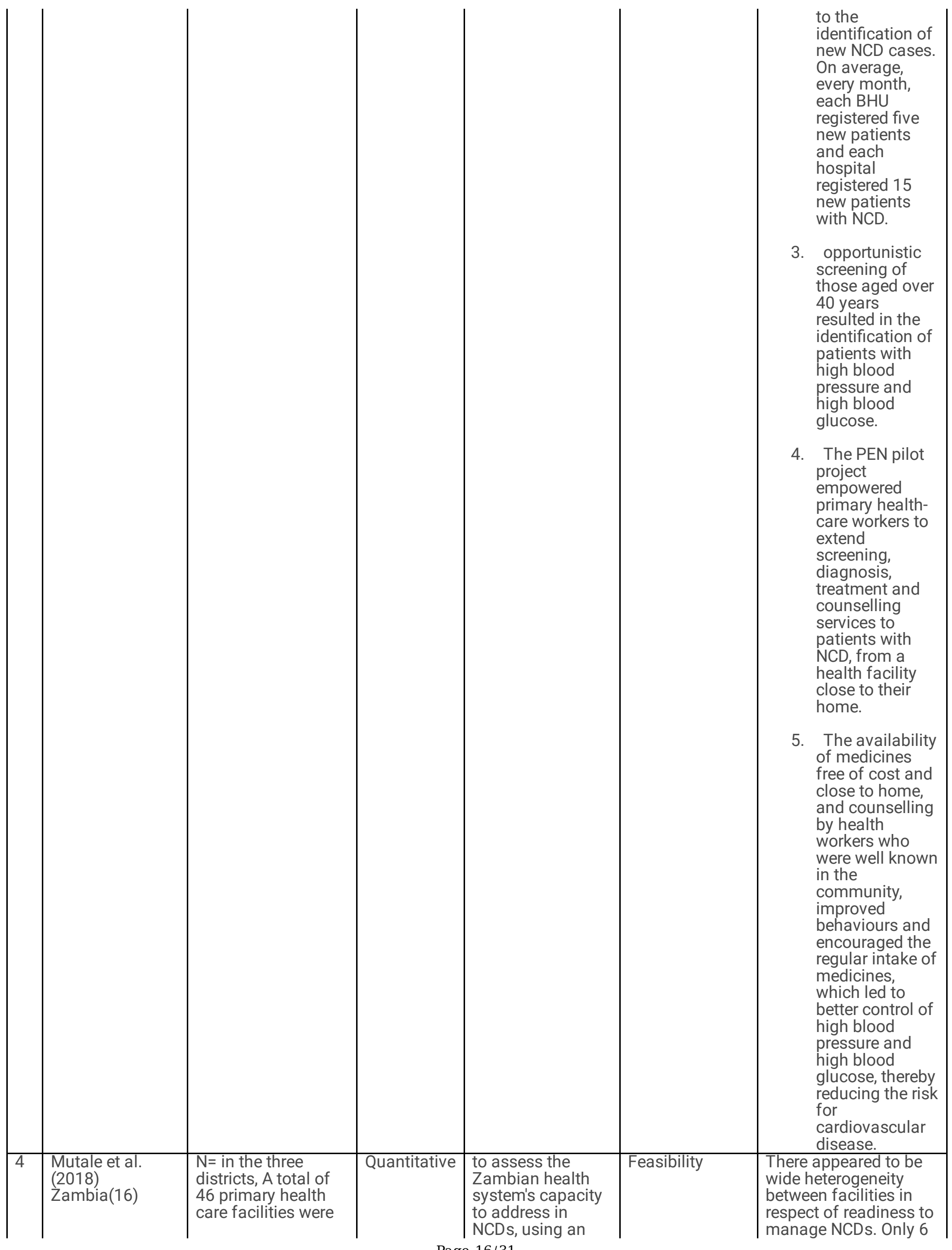

Page 16/31 


\begin{tabular}{|c|c|c|c|c|c|c|}
\hline & & $\begin{array}{l}\text { assessed and } 31 \text { st } \\
\text { level hospitals/ } \\
\text { This was a cross- } \\
\text { sectional facility } \\
\text { survey }\end{array}$ & & $\begin{array}{l}\text { adapted WH̄O } \\
\text { Essential } \\
\text { Non- } \\
\text { Communicable } \\
\text { Disease } \\
\text { Interventions } \\
\text { (WHO PEN) tool. }\end{array}$ & & $\begin{array}{l}\text { (including the three } 1 \mathrm{st} \\
\text { level hospitals) out of } \\
\text { the } 46 \text { facilities were } \\
\text { deemed ready to } \\
\text { manage NCDs. Only } \\
\text { the first level hospitals } \\
\text { scored a mean index } \\
\text { higher than the } 70 \% \\
\text { cut off; About } \\
\text { medications needed to } \\
\text { manage NCDs, urban } \\
\text { and rural health } \\
\text { facilities were } \\
\text { comparably equipped. }\end{array}$ \\
\hline 5 & $\begin{array}{l}\text { Ghanshyam Ahir } \\
\text { (2019) } \\
\text { Gujarat-India(17) }\end{array}$ & $\begin{array}{l}\mathrm{N}=\text { one PHC, One } \\
\mathrm{CHC} \text { and one urban } \\
\text { primary health } \\
\text { centre (UPHC)/ } \\
\text { This was a cross- } \\
\text { sectional/ } \\
\text { Data collection of } \\
\text { this Baseline study } \\
\text { was done with } \\
\text { pretested structured } \\
\text { monitoring tool } \\
\text { based on WHO PEN } \\
\text { / }\end{array}$ & Quantitative & $\begin{array}{l}\text { To find out facility- } \\
\text { level gaps for } \\
\text { prevention and } \\
\text { control of Non- } \\
\text { communicable } \\
\text { diseases and To } \\
\text { prepare } \\
\text { monitoring tool for } \\
\text { NCD prevention } \\
\text { and control } \\
\text { services }\end{array}$ & Feasibility & $\begin{array}{l}\text { Gaps regarding were } \\
\text { lack of trained health } \\
\text { personnel, no system } \\
\text { of collection of health } \\
\text { statistics about non- } \\
\text { communicable } \\
\text { diseases, Diagnostic } \\
\text { criteria, Treatment } \\
\text { protocol \& Referral } \\
\text { criteria was not } \\
\text { available. Only } \\
\text { screening criteria of } \\
\text { diabetes and } \\
\text { hypertension were } \\
\text { available. } \\
\text { Gaps do exist in the } \\
\text { human resource } \\
\text { capacity and service } \\
\text { delivery for NCD } \\
\text { prevention and control } \\
\text { at the primary care } \\
\text { level in both urban and } \\
\text { rural area and } \\
\text { secondary care level at } \\
\text { community health } \\
\text { centre assessed in } \\
\text { Bhavnagar district. }\end{array}$ \\
\hline 6 & $\begin{array}{l}\text { Binod Kumar } \\
\text { Aryal et al..(2018) } \\
\text { Nepal(18) }\end{array}$ & $\begin{array}{l}\mathrm{N}=92 \text { health } \\
\text { facilities/ } \\
\text { A descriptive cross- } \\
\text { sectional study/ }\end{array}$ & Quantitative & $\begin{array}{l}\text { to assess the } \\
\text { existing structure, } \\
\text { supply and service } \\
\text { system, facilities, } \\
\text { equipment, } \\
\text { medicine, } \\
\text { procedure and } \\
\text { capacity of health } \\
\text { institution to } \\
\text { deliver quality } \\
\text { services. }\end{array}$ & Feasibility & $\begin{array}{l}\text { Study reveals the } \\
\text { gaps in capacity } \\
\text { of health } \\
\text { institution and } \\
\text { system in terms } \\
\text { of training, } \\
\text { supply, } \\
\text { equipment, and } \\
\text { diagnostics. } \\
\text { However, training } \\
\text { of health workers, } \\
\text { supply of } \\
\text { essential } \\
\text { medicines and } \\
\text { improvising the } \\
\text { service delivery } \\
\text { would } \\
\text { supplement the } \\
\text { effective } \\
\text { implementation } \\
\text { of PEN in Nepal. } \\
\\
\text { The existing } \\
\text { status of the } \\
\text { health facilities } \\
\text { for the } \\
\text { implementation } \\
\text { of the PEN is } \\
\text { satisfactory. }\end{array}$ \\
\hline 7 & Bawazir et al & $\mathrm{N}=41$ out of $75 \mathrm{PHC}$ & Quantitative & to assess the & Feasibility & The findings of this \\
\hline
\end{tabular}

Page 17/31 


\begin{tabular}{|c|c|c|c|c|c|c|}
\hline & $\begin{array}{l}\text { (2019) } \\
\text { Saudi Arabia(19) }\end{array}$ & $\begin{array}{l}\text { facilities/ } \\
\text { A cross-sectional } \\
\text { study / } \\
\text { A rapid } \\
\text { standardized WHO } \\
\text { assessment } \\
\text { package tool (WHO- } \\
\text { PEN) was used to } \\
\text { assess the capacity } \\
\text { of the PHC services } \\
\text { in preventing and } \\
\text { control of NCDs. }\end{array}$ & & $\begin{array}{l}\text { capacity and } \\
\text { readiness of } \\
\text { primary healthcare } \\
\text { centres (PHC) for } \\
\text { the } \\
\text { implementation of } \\
\text { basic strategies } \\
\text { for the prevention } \\
\text { and control of } \\
\text { NCDs }\end{array}$ & & $\begin{array}{l}\text { study showed no } \\
\text { critical gap in the } \\
\text { capacity related to the } \\
\text { main areas of the } \\
\text { essential PHC services } \\
\text { to integrate and } \\
\text { manage NCDs }\end{array}$ \\
\hline 8 & $\begin{array}{l}\text { Kofi Mensah } \\
\text { Nyarko et al. } \\
\text { (2016) } \\
\text { Ghana(6) }\end{array}$ & $\begin{array}{l}\mathrm{N}=24 \text { health } \\
\text { facilities from the } \\
\text { three regions / } \\
\text { a cross-sectional } \\
\text { health facility-based } \\
\text { survey }\end{array}$ & Quantitative & $\begin{array}{l}\text { 1. to identify } \\
\text { existing } \\
\text { and } \\
\text { potential } \\
\text { gaps that } \\
\text { may } \\
\text { hamper the } \\
\text { smooth } \\
\text { deployment } \\
\text { of the } \\
\text { package } \\
\text { (PEN). } \\
\text { to } \\
\text { assessing } \\
\text { human } \\
\text { resource } \\
\text { capacity, } \\
\text { equipment, } \\
\text { service } \\
\text { utilization, } \\
\text { medicines } \\
\text { availability } \\
\text { and health } \\
\text { financing. }\end{array}$ & Feasibility & $\begin{array}{l}\text { The preparedness of } \\
\text { the health facilities for } \\
\text { the implementation of } \\
\text { WHO-PEN intervention } \\
\text { is unsatisfactory. Apart } \\
\text { from health financing, } \\
\text { major gaps in the } \\
\text { human resource } \\
\text { capacity, availability of } \\
\text { medications, } \\
\text { diagnostics, equipment } \\
\text { and medical } \\
\text { information } \\
\text { management system } \\
\text { are likely to hamper the } \\
\text { smooth } \\
\text { implementation of the } \\
\text { WHO-PEN intervention. }\end{array}$ \\
\hline 9 & $\begin{array}{l}\text { Rogers et al. } \\
(2018) \\
\text { Uganda(20) }\end{array}$ & $\begin{array}{l}\mathrm{N}=53 \text { public sector } \\
\text { health facilities/ } \\
\text { We developed a } \\
\text { survey guided by the } \\
\text { literature and the } \\
\text { standards of the } \\
\text { WHO PEN }\end{array}$ & Quantitative & $\begin{array}{l}\text { to: (1)assess their } \\
\text { capacity to detect } \\
\text { and manage } \\
\text { NCDs; (2)describe } \\
\text { provider } \\
\text { knowledge and } \\
\text { practices } \\
\text { regarding the } \\
\text { management of } \\
\text { NCDs; and } \\
\text { (3)identify areas } \\
\text { in need of focused } \\
\text { improvement. }\end{array}$ & Feasibility & $\begin{array}{l}\text { We identified } \\
\text { significant resource } \\
\text { gaps at all sampled } \\
\text { facilities. All facilities } \\
\text { reported deficiencies in } \\
\text { NCD screening and } \\
\text { management services. }\end{array}$ \\
\hline 10 & $\begin{array}{l}\text { Collins et al. } \\
\text { (2017) } \\
\text { Jordan(21) }\end{array}$ & $\begin{array}{l}\mathrm{N}=\text { Quantitative: We } \\
\text { included } 2907, \\
\text { Qualitative: We } \\
\text { interviewed } 16 \\
\text { participants/ } \\
\text { a mixed-methods } \\
\text { design of } \\
\text { quantitative and } \\
\text { qualitative strands } \\
\text { of equal priority }\end{array}$ & $\begin{array}{l}\text { a mixed } \\
\text { methods }\end{array}$ & $\begin{array}{l}\text { to identify } \\
\text { opportunities to } \\
\text { improve total CVD } \\
\text { risk-based } \\
\text { guidance for } \\
\text { humanitarian } \\
\text { settings. }\end{array}$ & Appropriateness & $\begin{array}{l}\text { This demonstrated } \\
\text { that despite the } \\
\text { implementation of } \\
\text { total CVD risk-based } \\
\text { guidance, few patients } \\
\text { had a documented and } \\
\text { correct CVD risk score, } \\
\text { and half of high risk } \\
\text { patients were not } \\
\text { prescribed lipid- } \\
\text { lowering treatment. } \\
\text { Many of the risk scores } \\
\text { document inpatient } \\
\text { records were } \\
\text { inaccurate; of patients } \\
\text { with a documented } \\
\text { low-risk score, one in } \\
\text { five were truly high } \\
\text { risk. The qualitative } \\
\text { analysis found nine }\end{array}$ \\
\hline
\end{tabular}

Page 18/31 


\begin{tabular}{|c|c|c|c|c|c|c|}
\hline & & & & & & $\begin{array}{l}\text { themes that together } \\
\text { helped theorise the } \\
\text { quantitative findings } \\
\text { and identify } \\
\text { opportunities to } \\
\text { improve the use of } \\
\text { total CVD risk-based } \\
\text { approaches in } \\
\text { humanitarian settings. }\end{array}$ \\
\hline 11 & $\begin{array}{l}\text { Dweakat et al. } \\
\text { (2017) } \\
\text { occupied } \\
\text { Palestinian } \\
\text { Territory(22) }\end{array}$ & $\begin{array}{l}\mathrm{N}=2200 \text { patients } \\
\text { with NCDs were } \\
\text { registered in } 14 \text { pilot } \\
\text { clinics/ } \\
\text { A clinical audit/ } \\
\text { A clinical audit was } \\
\text { implemented by the } \\
\text { completion of a } \\
\text { field-tested } \\
\text { questionnaire for } \\
\text { every patient's file } \\
\text { of a total of } 493 \\
\text { files, using } \\
\text { computer-generated } \\
\text { random sample } \\
\text { from the total list of } \\
2200 \text { registered } \\
\text { patients. Indicators } \\
\text { of file completeness } \\
\text { and staff adherence } \\
\text { to protocols were } \\
\text { used to assess the } \\
\text { quality of services. }\end{array}$ & Quantitative & $\begin{array}{l}\text { To assess the } \\
\text { quality of services } \\
\text { provided through } \\
\text { the new approach. }\end{array}$ & Fidelity & $\begin{array}{l}\text { The audit showed that } \\
\text { staff did generally } \\
\text { follow the PEN } \\
\text { protocols and } \\
\text { adequately completed } \\
\text { patient records. } \\
\text { However, problem } \\
\text { areas were highlighted, } \\
\text { notably risk } \\
\text { miscalculations ( } 119 \\
\text { of } 369 \text { files, } 32 \%) ; \\
\text { urine testing not } \\
\text { regularly done for } \\
\text { patients with diabetes } \\
\text { mellitus ( } 213 \text { of } 227 \\
\text { files, } 96 \%) ; \text { medical } \\
\text { plan for the next } \\
\text { scheduled visit not } \\
\text { mentioned (or written) } \\
\text { in the file ( } 251 \text { of } 470 \\
\text { files, } 53 \%) ; \text { cholesterol } \\
\text { testing done too } \\
\text { frequently (106 of } 471 \\
\text { files, } 23 \% \text { ); and, not } \\
\text { referring patients to } \\
\text { higher levels of care } \\
\text { according to the } \\
\text { protocol's criteria (14 } \\
\text { of } 471 \text { cases, } 3 \% \text { ). The } \\
\text { audit showed that in } \\
\text { more than } 10 \% \text { of } \\
\text { cases, doctors did not } \\
\text { take appropriate } \\
\text { clinical actions in the } \\
\text { face of clear } \\
\text { indications of NCD- } \\
\text { eg, failure to address } \\
\text { high blood pressure } \\
\text { and high blood } \\
\text { glucose. }\end{array}$ \\
\hline 12 & $\begin{array}{l}\text { Khan M Amir et } \\
\text { al. (2018) } \\
\text { Pakistan(23) }\end{array}$ & $\begin{array}{l}\mathrm{N}=14 \text { primary } \\
\text { healthcare facilities/ } \\
\text { The pragmatic } \\
\text { cluster randomised } \\
\text { controlled trial } \\
\text { (cRCT)/ } \\
\text { Clinics were } \\
\text { randomised on a 1:1 } \\
\text { basis (sealed } \\
\text { envelope lottery } \\
\text { method) and } 250 \\
\text { patients recruited in } \\
\text { the ACM arm and } \\
245 \text { in the TTR-only } \\
\text { arm (age } 25 \text { years } \\
\text { and HbA1c >7\%). } \\
\text { The primary } \\
\text { outcome was the } \\
\text { mean change in } \\
\text { HbA1c (\%) from } \\
\text { baseline to 9-month }\end{array}$ & Quantitative & $\begin{array}{l}\text { To assess if an } \\
\text { integrated care } \\
\text { package can } \\
\text { achieve better } \\
\text { control of } \\
\text { diabetes. }\end{array}$ & Appropriateness & $\begin{array}{l}\text { The ACM intervention } \\
\text { in public healthcare } \\
\text { facilities did not show } \\
\text { a statistically } \\
\text { significant effect on } \\
\text { HbA1c reduction } \\
\text { compared to the } \\
\text { control (TTR-only) arm. } \\
\text { Future evaluation } \\
\text { should assess } \\
\text { changes after a longer } \\
\text { follow-up period, and } \\
\text { minimal care } \\
\text { enhancement in the } \\
\text { comparator (control) } \\
\text { arm. }\end{array}$ \\
\hline
\end{tabular}




\begin{tabular}{|c|c|c|c|c|c|c|}
\hline & & $\begin{array}{l}\text { follow-up. Patients } \\
\text { and staff were not } \\
\text { blinded. }\end{array}$ & & & & \\
\hline 13 & $\begin{array}{l}\text { Latt et al. (2016) } \\
\text { Myanmar(8) }\end{array}$ & Perspective & Qualitative & $\begin{array}{l}\text { Analysis of the } \\
\text { gaps and } \\
\text { challenges in } \\
\text { diabetes care in } \\
\text { Myanmar is } \\
\text { expected to assist } \\
\text { in the formulation } \\
\text { and development } \\
\text { of a national } \\
\text { policy on NCDs } \\
\text { and its } \\
\text { implementation. }\end{array}$ & Penetration & $\begin{array}{l}\text { The World Health } \\
\text { Organization Package } \\
\text { of Essential } \\
\text { Noncommunicable } \\
\text { (PEN) disease } \\
\text { interventions for } \\
\text { primary health care in } \\
\text { low-resource settings } \\
\text { has been piloted in } \\
\text { Yangon Region and } \\
\text { countrywide expansion } \\
\text { awaits ministerial } \\
\text { approval. Recently, the } \\
\text { Myanmar Diabetes } \\
\text { Care Model was } \\
\text { proposed by the } \\
\text { Myanmar Diabetes } \\
\text { Association, with the } \\
\text { aims of both bridging } \\
\text { the gap in diabetes } \\
\text { care between rural and } \\
\text { urban areas and } \\
\text { strengthening care at } \\
\text { the secondary and } \\
\text { tertiary levels. However, } \\
\text { implementation will } \\
\text { require policy } \\
\text { development for } \\
\text { essential drugs and } \\
\text { equipment, capacity- } \\
\text { strengthening of } \\
\text { health-care workers, } \\
\text { and an appropriate } \\
\text { referral and health } \\
\text { information system. }\end{array}$ \\
\hline 14 & $\begin{array}{l}\text { Mendis and et al. } \\
\text { ( 2012) } \\
\text { eight LMIC(2 } \\
\text { low-income } \\
\text { countries: Benin, } \\
\text { Eritrea; } 4 \text { low- } \\
\text { middle-income } \\
\text { countries: Sudan, } \\
\text { Bhutan, Sri } \\
\text { Lanka, Vietnam; } \\
2 \text { upper-middle- } \\
\text { income } \\
\text { countries: } \\
\text { Suriname and } \\
\text { Syria)(7) }\end{array}$ & $\begin{array}{l}\mathrm{N}=90 \text { PC facilities/ } \\
\text { A cross-sectional } \\
\text { survey/ }\end{array}$ & Quantitative & $\begin{array}{l}\text { to evaluate the } \\
\text { capacity of } \\
\text { primary care (PC) } \\
\text { facilities to } \\
\text { implement basic } \\
\text { interventions for } \\
\text { prevention and } \\
\text { management of } \\
\text { major non- } \\
\text { communicable } \\
\text { diseases (NCDs), } \\
\text { including } \\
\text { cardiovascular } \\
\text { diseases and } \\
\text { diabetes. }\end{array}$ & Feasibility & $\begin{array}{l}\text { Major deficits were } \\
\text { identified in health } \\
\text { financing, access to } \\
\text { basic technologies and } \\
\text { medicines, medical } \\
\text { information systems, } \\
\text { and the health } \\
\text { workforce. The study } \\
\text { has provided the } \\
\text { foundation for } \\
\text { strengthening the PC } \\
\text { to address } \\
\text { noncommunicable } \\
\text { diseases. There are } \\
\text { important implications } \\
\text { of the findings of this } \\
\text { study for all low- and } \\
\text { middle-income } \\
\text { countries as capacity } \\
\text { of PC is fundamental } \\
\text { for equitable } \\
\text { prevention and control } \\
\text { of NCDs. }\end{array}$ \\
\hline 15 & $\begin{array}{l}\text { Anna } \\
\text { Kontsevaya and } \\
\text { Jill Farrington } \\
\text { (2017) } \\
\text { Kyrgyzstan(24) }\end{array}$ & $\begin{array}{l}\mathrm{N}=481213 \\
\text { population / } \\
\text { the retrospective } \\
\text { evaluation of the } \\
\text { implementation of } \\
\text { the PEN protocols/ } \\
\text { The evaluation } \\
\text { included } \\
\text { performance/quality }\end{array}$ & Quantitative & $\begin{array}{l}\text { The study aimed } \\
\text { to: } \\
\text { - compare the } \\
\text { inputs, outputs } \\
\text { and outcomes for } \\
\text { PEN pilot sites } \\
\text { versus non-PEN } \\
\text { pilot sites in } \\
\text { Bishkek city for } 12 \\
\text { months; }\end{array}$ & Appropriateness & $\begin{array}{l}\text { In general, } \\
\text { additional costs } \\
\text { per year per } \\
\text { FMC, including } \\
\text { the costs of } \\
\text { preparation and } \\
\text { implementation, } \\
\text { were low (US\$ } \\
\text { 866). Only three } \\
\text { FMC needed to } \\
\text { buy the }\end{array}$ \\
\hline
\end{tabular}

Page 20/31 


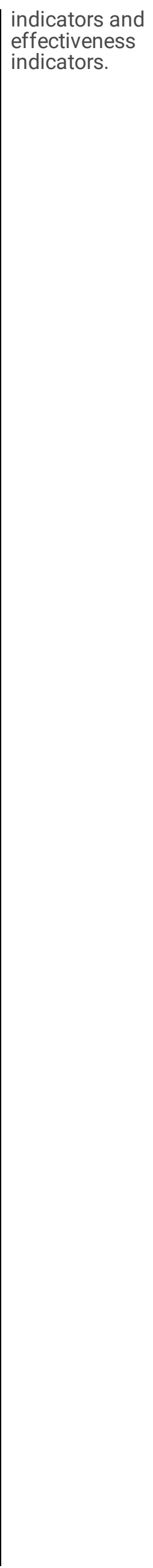

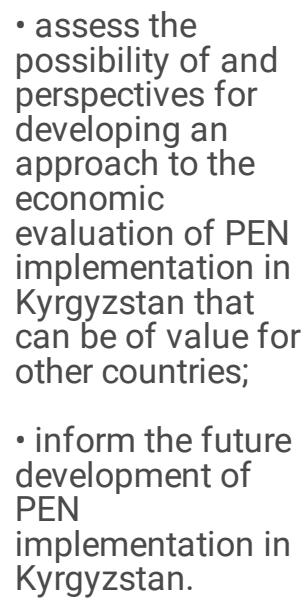

additional equipment; the other seven had it already.

For all

indicators, the $\mathrm{Cl}$ were

overlapping, indicating no statistically significant difference over time. In PEN centres in 12 months after the implementation of the PEN protocols, the number of visits by patients with blood pressure both above and below the recommended thresholds per 100000 population appeared to double compared with the period before implementation of PEN. Even if this were statistically significant, it would be difficult to interpret as it could reflect changes in detection through screening (probable) rather than changes in blood pressure control (possible).

The evaluation of the short-term effects 12 months' in terms of changes in prespecified performance and effectiveness indicators in PEN centres did not show clear and significant evidence of a real impact resulting from the implementation of the PEN protocols on primary care, so there were no 


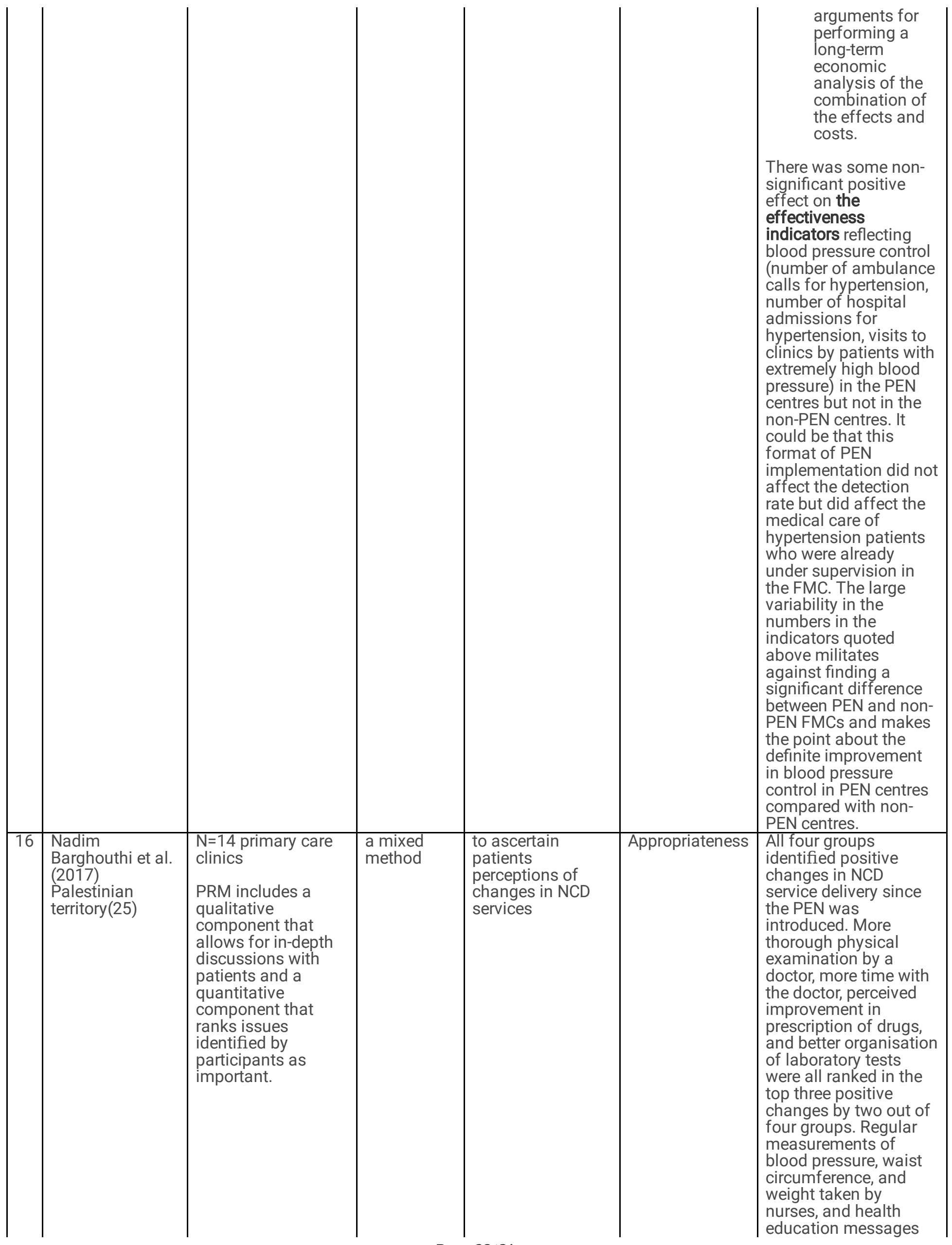

Page 22/31 


\begin{tabular}{|c|c|c|c|c|c|c|}
\hline & & & & & & $\begin{array}{l}\text { provided by nurses to } \\
\text { patients as part of the } \\
\text { protocol, in addition to } \\
\text { shorter waiting times } \\
\text { were in the top eight } \\
\text { improvements noted } \\
\text { by all four groups. } \\
\text { Additionally, } \\
\text { application of an } \\
\text { appointment system } \\
\text { was identified as a } \\
\text { positive change by } \\
\text { three groups. Both } \\
\text { male groups } \\
\text { appreciated an } \\
\text { increased follow-up } \\
\text { period between visits, } \\
\text { whereas neither group } \\
\text { of women mentioned } \\
\text { this as a substantial } \\
\text { factor. No negative } \\
\text { perceptions related to } \\
\text { the PEN were } \\
\text { expressed. }\end{array}$ \\
\hline 17 & $\begin{array}{l}\text { Zhang et al. } \\
(2016) \\
\text { China(4) }\end{array}$ & A Policy Statement & Qualitative & $\begin{array}{l}\text { Policy Statement } \\
\text { on the } \\
\text { Implementation of } \\
\text { the World Health } \\
\text { Organization's } \\
\text { Non- } \\
\text { Communicable } \\
\text { Diseases } \\
\text { Intervention } \\
\text { Package for } \\
\text { Primary Health } \\
\text { Care in low } \\
\text { Resources setting }\end{array}$ & Appropriateness & $\begin{array}{l}\text { The World } \\
\text { Hypertension League } \\
\text { recommends the } \\
\text { implementation of } \\
\text { WHO PEN in low- } \\
\text { resource settings as a } \\
\text { cost-effective and } \\
\text { equitable means to } \\
\text { control hypertension in } \\
\text { the context of other } \\
\text { NCDs and health risks. } \\
\text { People with NCDs } \\
\text { require long-term care } \\
\text { that is proactive, } \\
\text { patient-centred, } \\
\text { community-based, and } \\
\text { sustainable. Such care } \\
\text { can be delivered } \\
\text { equitably only through } \\
\text { health systems based } \\
\text { on primary healthcare. } \\
\text { The implementation of } \\
\text { the WHO PEN } \\
\text { interventions will not } \\
\text { only help to reduce the } \\
\text { burden of NCDs and } \\
\text { hypertension, but } \\
\text { strengthen the } \\
\text { efficiency and equity } \\
\text { of the health system. }\end{array}$ \\
\hline 18 & $\begin{array}{l}\text { Sanjay Basu et } \\
\text { al. (2018) } \\
\text { South Africa(26) }\end{array}$ & $\begin{array}{l}\mathrm{N}=17743 \\
\text { respondents aged } \\
15 \text { years or older/ } \\
\text { Cost-effectiveness } \\
\text { analysis }\end{array}$ & Quantitative & $\begin{array}{l}\text { To assessed how } \\
\text { cardiovascular } \\
\text { risk factors are } \\
\text { distributed across } \\
\text { subpopulations } \\
\text { within South } \\
\text { Africa and } \\
\text { identified which } \\
\text { cardiovascular } \\
\text { treatments should } \\
\text { be prioritised. }\end{array}$ & Cost & $\begin{array}{l}\text { The incremental cost- } \\
\text { effectiveness of } \\
\text { implementing SA PC } \\
101 \text { over current } \\
\text { treatment would be a } \\
\text { saving of US\$24 } 902 \\
\text { (95\% Cl } 14666-62 \\
579) \text { per DALY averted } \\
\text { compared with a } \\
\text { saving of } \$ 17587 \\
\text { (1840-42 589) under } \\
\text { WHO PEN guidelines. } \\
\text { With the } \\
\text { implementation } \\
\text { of the WHO } \\
\text { PEN guidelines, } \\
\text { we would }\end{array}$ \\
\hline
\end{tabular}

Page 23/31 
anticipate a

considerably

higher

proportion of

the population

treated with

statins,

followed by

increased

treatment for

hypertension

and then

glycaemic

control for

diabetes. But

we additionally

found that

implementation

of the SA PC

101 guidelines

averted slightly

more overall

DALYs and had

better cost-

effectiveness

than

implemented

the WHO PEN

guidelines. The

key benefits of

the SA PC 101

guidelines in

terms of DALYs

was a result of

more assertive

blood pressure

treatment,

particularly for

high-risk

patients,

whereas the

benefits, in

terms of costs, were primarily

from less

assertive blood

glucose control

than under the

WHO PEN

guidelines. We

found that if

either

guidelines were

implemented

with coverage

rates similar to

a well-

performing

European

health system,

the Sustainable

Development

Goals target 3.4

(reduction in

premature

mortality from

non-

communicable

diseases of one third) would be

readily

achieved. 


\begin{tabular}{|c|c|c|c|c|c|c|}
\hline 19 & $\begin{array}{l}\text { Dylan Collins et } \\
\text { al. } \\
\text { (2017) } \\
\text { Kyrgyzstan(27) }\end{array}$ & $\begin{array}{l}\mathrm{N}=30 \\
\text { participants(15 } \\
\text { doctors and } 15 \\
\text { nurses)/ } \\
\text { the retrospective } \\
\text { evaluation and } \\
\text { interview(pilot } \\
\text { study) }\end{array}$ & $\begin{array}{l}\text { a mixed } \\
\text { methods }\end{array}$ & $\begin{array}{l}\text { to identify } \\
\text { opportunities to } \\
\text { improve the } \\
\text { implementation of } \\
\text { PEN in } \\
\text { Kyrgyzstan. }\end{array}$ & Appropriateness & $\begin{array}{l}\text { Qualitative analysis } \\
\text { found } 11 \text { themes } \\
\text { which seemed to help } \\
\text { explain the } \\
\text { quantitative findings. } \\
\text { Eleven themes were } \\
\text { identified which are } \\
\text { categorized as } \\
\text { provider-centred and } \\
\text { patient-centred. } \\
\text { Implementation of a } \\
\text { total cardiovascular } \\
\text { risk approach, in this } \\
\text { case through the PEN } \\
\text { protocols and risk } \\
\text { prediction charts, } \\
\text { would benefit from } \\
\text { multifaceted and } \\
\text { repeated training, } \\
\text { maintenance of the } \\
\text { quality of intervention, } \\
\text { systematic approaches } \\
\text { to identifying the target } \\
\text { population and } \\
\text { achieving coverage, } \\
\text { and a simpler } \\
\text { workflow. Overall the } \\
\text { concept is well- } \\
\text { received by providers } \\
\text { but its implementation } \\
\text { needs fine-tuning and } \\
\text { to draw more upon } \\
\text { evidence-based } \\
\text { approaches to the } \\
\text { implementation of } \\
\text { clinical guidelines and } \\
\text { changing clinical } \\
\text { practice. Similarly, the } \\
\text { engagement of } \\
\text { patients and } \\
\text { increasing coverage of } \\
\text { the target population is } \\
\text { likely to need a } \\
\text { combination of } \\
\text { supportive push and } \\
\text { pull factors. }\end{array}$ \\
\hline 20 & $\begin{array}{l}\text { Wangchuk } \\
\text { Dukpa et al. } \\
\text { (2015) } \\
\text { Bhutan(28) }\end{array}$ & $\begin{array}{l}\text { A model-based } \\
\text { economic } \\
\text { evaluation }\end{array}$ & Quantitative & $\begin{array}{l}\text { To assessing the } \\
\text { cost-effectiveness } \\
\text { of the PEN project } \\
\text { implemented in } \\
\text { Bhutan and } \\
\text { analysing the } \\
\text { costs and health } \\
\text { consequences of } \\
\text { the program in } \\
\text { both the short and } \\
\text { long term. }\end{array}$ & Cost & $\begin{array}{l}\text { 1. Results } \\
\text { confirm that the } \\
\text { current PEN } \\
\text { program and } \\
\text { universal } \\
\text { screening are } \\
\text { certainly cost- } \\
\text { effective and, } \\
\text { most likely, cost- } \\
\text { saving options } \\
\text { in Bhutan. } \\
\text { The cost- } \\
\text { effectiveness } \\
\text { acceptability } \\
\text { curves for all } \\
\text { options and } \\
\text { demonstrates } \\
\text { that both the } \\
\text { current PEN } \\
\text { program and } \\
\text { universal } \\
\text { screening are }\end{array}$ \\
\hline
\end{tabular}


superior to no

screening, at

any willingnessto-pay

threshold.

3. The current PEN program is shown to be a cost-saving intervention, as long as the prevalence of diabetes and hypertension is higher than 0.3 per 1000 people in the population. .This is significantly lower than the current prevalence of diabetes and hypertension in Bhutan, which is 342 per 1000 people in the population.

4. The results support the WHO's standpoint, which indicates that the WHO PEN is very cost-effective and feasible to implement in all countries.

5. As a result, we believe that the results of the analysis are likely to be conservative and the scalingup of diabetic and hypertension screenings to a national-wide program should be a priority in Bhutan.

6. This study further recommends universal screening instead of opportunistic screening at primary care facilities because of the relatively high prevalence of diabetes in the 


\begin{tabular}{|c|c|c|c|c|c|c|}
\hline & & & & & & $\begin{array}{l}\quad \text { Bhutanese } \\
\text { population. } \\
\text { From the sensitivity } \\
\text { analysis, the value of } \\
\text { the screening options } \\
\text { remains the same } \\
\text { when disease } \\
\text { prevalence varies. } \\
\text { Therefore, applying } \\
\text { this model to other } \\
\text { healthcare settings is } \\
\text { warranted, since } \\
\text { disease prevalence is } \\
\text { one of the major } \\
\text { factors in affecting the } \\
\text { cost-effectiveness } \\
\text { results of screening } \\
\text { programs. }\end{array}$ \\
\hline 21 & $\begin{array}{l}\text { Rattanavipapong } \\
\text { et al. } \\
\text { (2016) } \\
\text { Indonesia(29) }\end{array}$ & $\begin{array}{l}\text { Model-Based } \\
\text { Economic } \\
\text { Evaluation }\end{array}$ & Quantitative & $\begin{array}{l}\text { To evaluate the } \\
\text { cost-effectiveness } \\
\text { of the PEN } \\
\text { program } \\
\text { compared to a "no } \\
\text { screening" policy } \\
\text { choice. }\end{array}$ & Cost & $\begin{array}{l}\text { Cost-Effectiveness } \\
\text { Results-Providing the } \\
\text { current PEN policy had } \\
\text { the greatest health } \\
\text { benefits in terms of the } \\
\text { lowest DALYs lost or } \\
\text { highest DALYs averted } \\
\text { compared to no } \\
\text { screening } \\
\text { Budget Impact } \\
\text { Analysis-The results } \\
\text { indicate that annual } \\
\text { total budget impact for } \\
\text { the current PEN } \\
\text { program is } \\
\text { approximately } 565 \\
\text { trillion IDR for the first } \\
\text { year and } 2,750 \text { trillion } \\
\text { IDR over five years. }\end{array}$ \\
\hline 22 & $\begin{array}{l}\text { Choe et al. } \\
\text { (2017) } \\
\text { Democratic } \\
\text { People's Republic } \\
\text { of Korea(30) }\end{array}$ & $\begin{array}{l}\mathrm{N}=32000 \\
\text { population/ } \\
\text { the feasibility study/ } \\
\text { The performance of } \\
\text { the pilot project was } \\
\text { evaluated in } \\
\text { December } 2015 . \\
\text { Based on the WHO } \\
\text { health-system } \\
\text { evaluation } \\
\text { framework, a pilot } \\
\text { project-evaluation } \\
\text { framework was } \\
\text { prepared in } \\
\text { consultation with } \\
\text { the program } \\
\text { managers. }\end{array}$ & Quantitative & $\begin{array}{l}\text { to assess the } \\
\text { feasibility of } \\
\text { integrating the } \\
\text { interventions into } \\
\text { the existing } \\
\text { primary healthcare } \\
\text { system. }\end{array}$ & Feasibility & 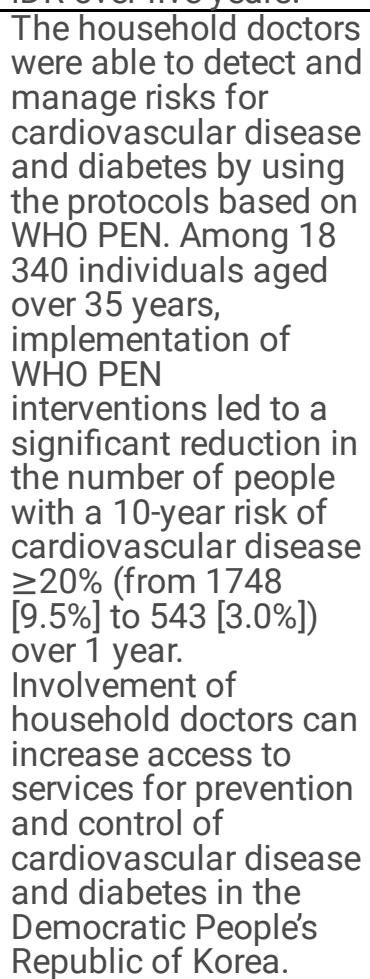 \\
\hline 23 & $\begin{array}{l}\text { Wangchuk et al. ( } \\
\text { 2014) } \\
\text { Bhutan(31) }\end{array}$ & $\begin{array}{l}\text { a performance } \\
\text { assessment } \\
\text { study(Descriptive } \\
\text { analysis \& before- } \\
\text { after analysis) }\end{array}$ & Quantitative & $\begin{array}{l}\text { The performance } \\
\text { of the PEN project } \\
\text { in detecting and } \\
\text { managing non- } \\
\text { communicable }\end{array}$ & Appropriateness & $\begin{array}{l}\text { In } 3 \text { months, } 39079 \\
\text { patients had attended } \\
\text { clinics in the pilot } \\
\text { districts. About } 10 \% \text { of } \\
\text { the clinic attendees }\end{array}$ \\
\hline
\end{tabular}

Page 27/31 


\begin{tabular}{|c|c|c|c|c|c|c|}
\hline & & & & $\begin{array}{l}\text { diseases (NCDs) } \\
\text { and their risk } \\
\text { factors was } \\
\text { assessed. }\end{array}$ & & $\begin{array}{l}\text { (3818/39 079) were } \\
\text { aged over } 40 \text { years; of } \\
\text { these, } 22.6 \% \\
(864 / 3818) \text { had a high } \\
\text { blood pressure, and } \\
49.7 \%(1896 / 3818) \\
\text { were overweight/obese } \\
\text { or had a high waist } \\
\text { circumference. } \\
\text { Screening of } \\
\text { overweight/obese/high } \\
\text { waist circumference } \\
\text { cases revealed that } \\
26.1 \% \text { ( } 494 / 1896) \text { had } \\
\text { high blood sugar } \\
\text { levels. Out of the } 896 \\
\text { patients who were } \\
\text { registered on PEN } \\
\text { protocols, } 13 \% \text { had } \\
>20 \% \text { risk of } \\
\text { developing } \\
\text { cardiovascular } \\
\text { diseases (CVDs) in } \\
\text { next } 10 \text { years as per } \\
\text { the WHO/International } \\
\text { Society of } \\
\text { Hypertension risk- } \\
\text { assessment charts. } \\
\text { Among } 444 \text { who had } \\
\text { three follow-up visits, } \\
\text { high } 10-y \text { ear-CVD risk } \\
(>20 \%) \text { had declined } \\
\text { from } 13 \% \text { to } 7.3 \% \text {. } \\
\text { Among } 400 \text { persons } \\
\text { with hypertension, use } \\
\text { of medication } \\
\text { increased and high } \\
\text { blood pressure } \\
\text { declined from } 42.3 \% \text { to } \\
21.5 \% \text {. Among } 115 \\
\text { persons with diabetes, } \\
\text { use of anti-diabetes } \\
\text { medication increased } \\
\text { and high blood sugar } \\
\text { declined from } 68 / 100 \\
\text { to } 51 / 100 \text {. }\end{array}$ \\
\hline 24 & $\begin{array}{l}\text { Jarvis JD et al. } \\
(2019)(32)\end{array}$ & $\begin{array}{l}\text { Three lists of } \\
\text { WHO(Best Buys- } \\
\text { PEN- HEARTS) } \\
\text { endorsed priority } \\
\text { NCD interventions } \\
\text { were included. A } \\
\text { database with } 137 \\
\text { national Essential } \\
\text { Medicines List } \\
\text { (EMLs) and the } \\
\text { WHO EML was } \\
\text { created from the } \\
\text { WHO Repository } \\
\text { and these EMLS } \\
\text { were compared for a } \\
\text { listing of priority } \\
\text { NCD interventions. }\end{array}$ & Quantitative & $\begin{array}{l}\text { To determine } \\
\text { across a wide } \\
\text { range of countries } \\
\text { which national } \\
\text { EMLs have listed } \\
\text { the priority NCD } \\
\text { interventions } \\
\text { recommended by } \\
\text { WHO NCD } \\
\text { packages and } \\
\text { guidelines. }\end{array}$ & Penetration & $\begin{array}{l}\text { Across } 137 \text { countries } \\
\text { with national EMLs, } \\
\text { the median percentage } \\
\text { of } 20 \text { Best Buys } \\
\text { interventions listed } \\
\text { was } 90 \% \text { (IQR } 80-95 \text { ) } \\
\text { and } 31 \text { Package of } \\
\text { essential } \\
\text { noncommunicable } \\
\text { disease interventions } \\
\text { (PEN) interventions } \\
\text { listed was } 94 \% \text { (IQR } \\
90-97) \text {, of } 9 \text { HEARTS } \\
\text { interventions was } \\
100 \% \text { (IQR } 89-100), \\
\text { and of the } 43 \text { unique } \\
\text { interventions across } \\
\text { the three priority lists } \\
\text { was } 88 \% \text { (IQR } 84-93 \text { ). } \\
\text { The median } \\
\text { percentage of } \\
\text { countries that included } \\
\text { each of the } 31 \\
\text { interventions } \\
\text { recommended in the } \\
\text { PEN priority list was }\end{array}$ \\
\hline
\end{tabular}

Page 28/31 


\begin{tabular}{|c|c|c|c|c|c|c|}
\hline & & & & & & $\begin{array}{l}94 \% \text { ( } 129 \text { of } 137) \text { (IQR: } \\
89-98 \%) \text {, that is, PEN } \\
\text { priority medicines were } \\
\text { included in most } \\
\text { national EMLs. The } \\
\text { priority intervention } \\
\text { included in the fewest } \\
\text { national EMLs was } \\
\text { senna ( } 47 \text { of } 137 \\
\text { countries, } 34 \% \text { ). The } \\
\text { median percentage of } \\
\text { PEN medicines } \\
\text { included by each } \\
\text { country was } 94 \% \text { ( } 29 \\
\text { of } 31 \text { ) (IQR: } 90-97 \%), \\
\text { that is, national EMLs } \\
\text { included most priority } \\
\text { medicines. Thirteen } \\
\text { countries had a } \\
\text { coverage rate of } 100 \% \text {, } \\
\text { meaning they included } \\
\text { all } 31 \text { medicines or } \\
\text { medicine classes on } \\
\text { their EML. }\end{array}$ \\
\hline 25 & $\begin{array}{l}\text { Upreti et al. } \\
\text { (2016) } \\
\text { Nepal(5) }\end{array}$ & Perspective & Qualitative & $\begin{array}{l}\text { Addressing the } \\
\text { growing burden of } \\
\text { diabetes in Nepal }\end{array}$ & Appropriateness & $\begin{array}{l}\text { The lack of awareness, } \\
\text { inadequate services for } \\
\text { diabetes management, } \\
\text { including early } \\
\text { detection, the cost of } \\
\text { services, and the } \\
\text { country's topography } \\
\text { are barriers to diabetes } \\
\text { care. } \\
\text { The government of } \\
\text { Nepal therefore has an } \\
\text { opportunity to } \\
\text { strengthen health-care } \\
\text { services via primary } \\
\text { health-care facilities, } \\
\text { by implementing the } \\
\text { essential package of } \\
\text { NCD interventions. } \\
\text { Phased } \\
\text { implementation and } \\
\text { escalation of coverage } \\
\text { of PEN in all 75 } \\
\text { districts30 brings } \\
\text { opportunities to } \\
\text { strengthen the health } \\
\text { workforce, diagnostics, } \\
\text { medicines and } \\
\text { supplies, the health } \\
\text { information system, } \\
\text { research and } \\
\text { surveillance and } \\
\text { reduce inequity in } \\
\text { diabetes care in Nepal. } \\
\text { To strengthen the roll- } \\
\text { out of PEN in Nepal, } \\
\text { we recommend } \\
\text { revision of the free } \\
\text { essential medicines list } \\
\text { of the Ministry of } \\
\text { Health and Population, } \\
\text { to cover essential } \\
\text { drugs for management } \\
\text { of NCDs. }\end{array}$ \\
\hline 26 & $\begin{array}{l}\text { Martinez et al. } \\
\text { (2015) }\end{array}$ & $\begin{array}{l}\text { This brief report } \\
\text { describes the }\end{array}$ & Quantitative & $\begin{array}{l}\text { These assessed } \\
\text { the use of the PEN }\end{array}$ & Appropriateness & $\begin{array}{l}\text { After six months, two } \\
\text { of the four PEN }\end{array}$ \\
\hline
\end{tabular}

Page 29/31 


\begin{tabular}{|c|c|c|c|}
\hline Philippines(33) & $\begin{array}{l}\text { implementation of } \\
\text { two of the four PEN } \\
\text { protocols in Region } \\
8 \text { - Protocol } 1 \text { on } \\
\text { managing and } \\
\text { preventing heart } \\
\text { attack, stroke and } \\
\text { renal disease and } \\
\text { Protocol } 2 \text { on health } \\
\text { education and } \\
\text { promotion and } \\
\text { smoking cessation. }\end{array}$ & $\begin{array}{l}\text { protocols, } \\
\text { availability of PEN } \\
\text { implementation } \\
\text { tools and whether } \\
\text { the } \\
\text { implementation } \\
\text { targets for Region } \\
8 \text { had been met. }\end{array}$ & $\begin{array}{l}\text { indicators had been } \\
\text { met in Region 8: all } \\
\text { primary health care } \\
\text { facilities had trained } \\
\text { health service } \\
\text { providers and } \\
\text { complete sets of } \\
\text { essential equipment. } \\
\text { The other two } \\
\text { indicators had not } \\
\text { been met as only } 19 \% \\
\text { of monitored primary } \\
\text { health care facilities } \\
\text { had complete sets of } \\
\text { essential medicines } \\
\text { provided by the DOH } \\
\text { and only } 44 \% \text { were } \\
\text { implementing PEN } \\
\text { where the target for } \\
\text { each was } 80 \% \text {. }\end{array}$ \\
\hline
\end{tabular}

\section{Figures}

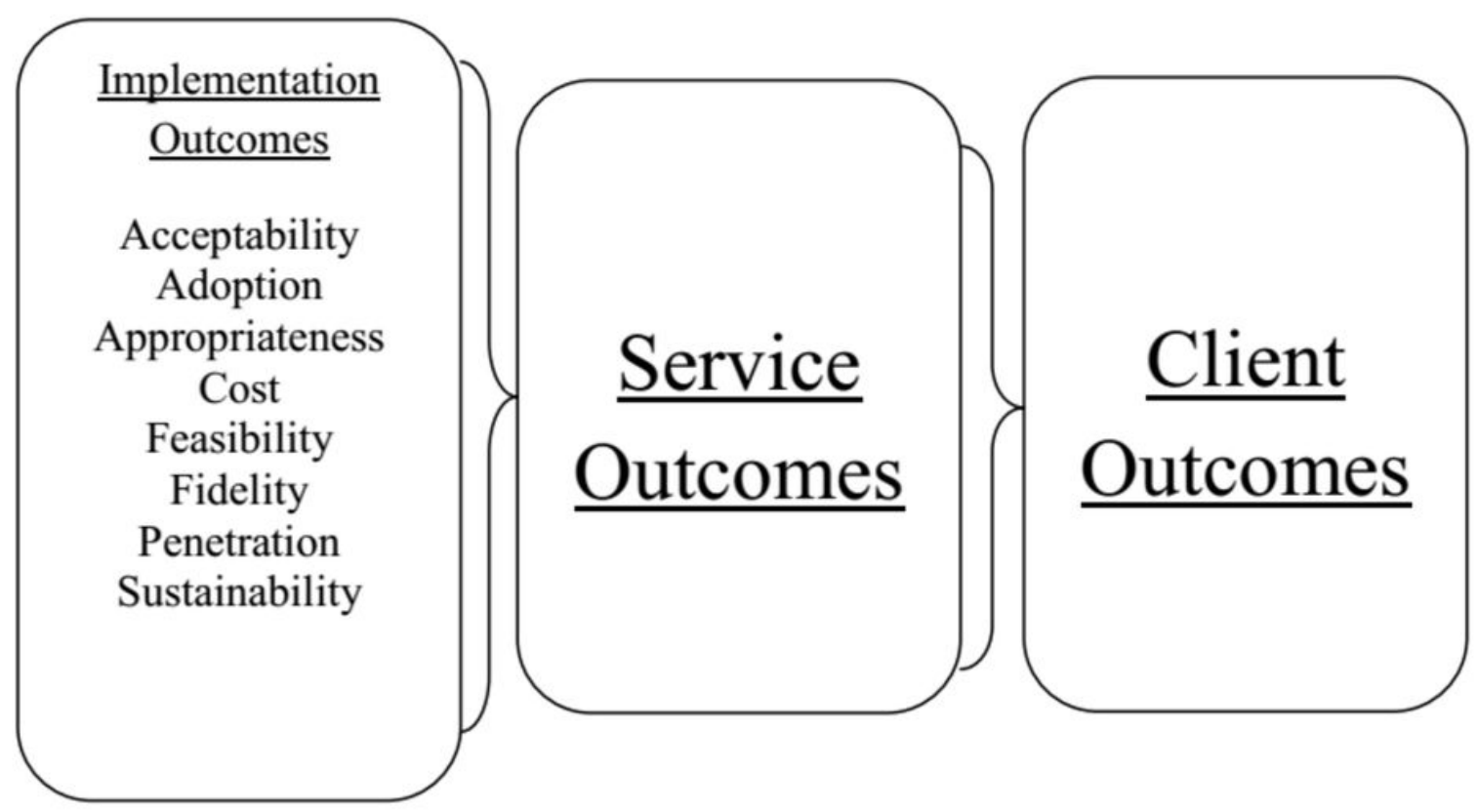

Fig.1 Implementation research conceptual model

Figure 1

Implementation research conceptual model 


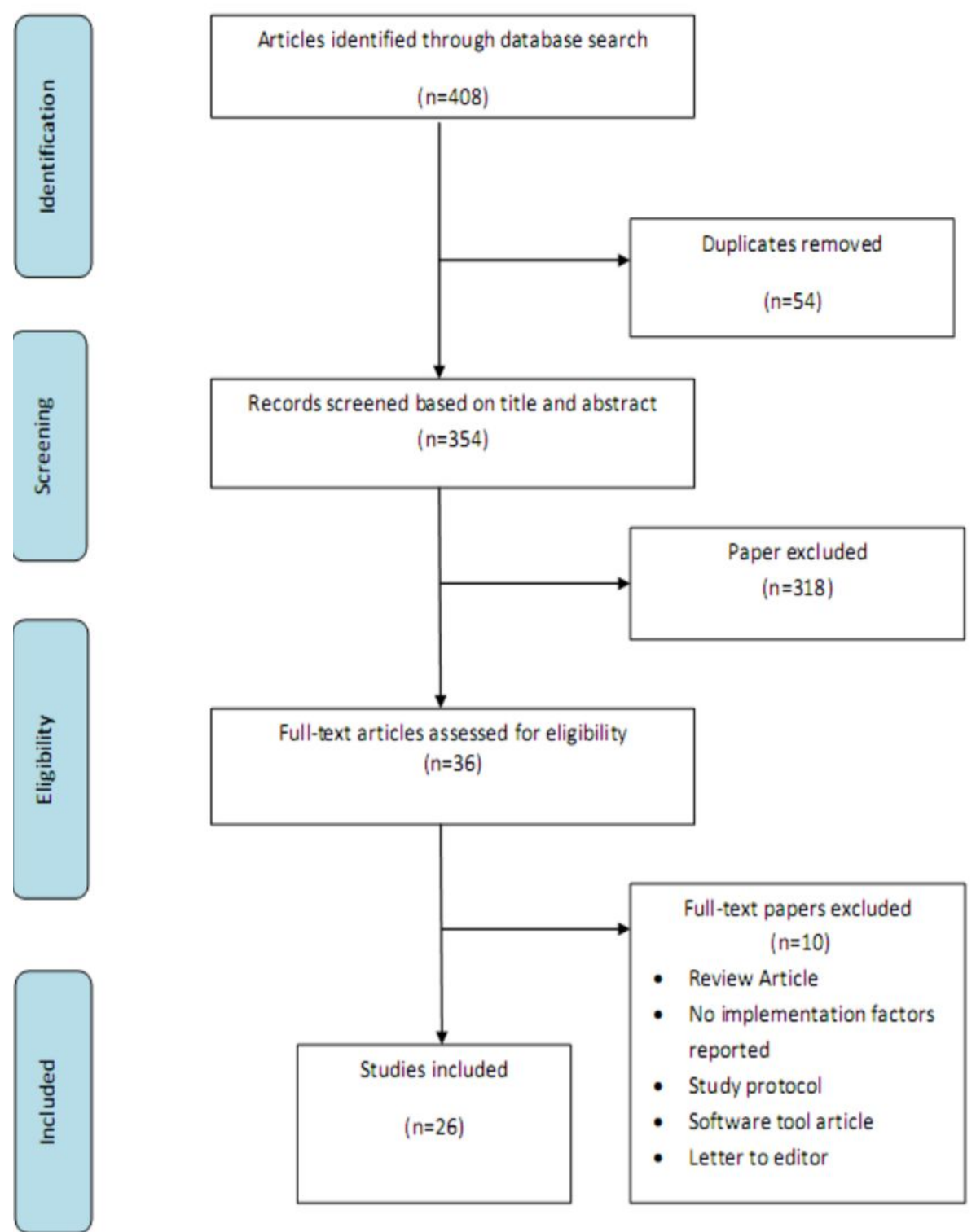

Fig 2.Process of selecting studies for scoping review

Figure 2

Process of selecting studies for scoping review

\section{Supplementary Files}

This is a list of supplementary files associated with this preprint. Click to download.

- PRISMA2009checklist1.pdf 